\title{
Ortaokul Öğrencilerinin İstatistiksel Grafikleri Okuma ve Yorumlama Düzeylerinin İncelenmesi *
}

\section{Hatice Kübra Güler ${ }^{1} \quad$ Makbule Gözde Didiş Kabar²}

\section{Type/Tür:}

Research/Araştırma

Received/Geliş Tarihi: January

20/ 20 Ocak 2020

Accepted/Kabul Tarihi:

December 5/5 Aralık 2020

Page numbers/Sayfa No: $23-52$

Corresponding

Author/İletişimden Sorumlu

Yazar: gozde.didis@gop.edu.tr

\section{iThenticate}

This paper was checked for plagiarism using iThenticate during the preview process and before publication. / Bu çalışma ön inceleme sürecinde ve yayımlanmadan önce iThenticate yazılımı ile taranmıştır.

\section{Copyright (C) 2017 by}

Cumhuriyet University, Faculty of Education. All rights reserved.

\section{Öz}

İyi bir tüketici, vatandaş ve çalışan olmak için istatistiksel okuryazarlığın kişisel yaşamımızda önemli bir yeri olduğu vurgulanmaktadır. İstatistiksel grafikleri okuyabilmek ve yorumlayabilmek istatistiksel okuryazarlığın önemli bir parçasını oluşturmaktadır. Öğrencilerin gazete ve dergi gibi farklı kanallar aracılığıyla karşılarına çıkan grafikle sunulan bilgileri okuyup yorumlayabilmeleri önem arz etmektedir. Nitel araştırma yöntemlerinden durum çalışması olarak tasarlanan bu çalışmada, beş tane yedinci sınıf öğrencisinin sütun ve daire grafiklerini okuma ve yorumlama düzeylerinin incelenmesi amaçlanmıştır. Bu amaçla, bu çalışma 2017-2018 eğitim-öğretim yılının bahar döneminde, Sivas ilinin Hafik ilçesinde yer alan bir devlet ortaokulunda öğrenim görmekte olan beş (4 kız, 1 erkek) adet yedinci sınıf öğrencisi ile gerçekleştirilmiştir. $\mathrm{Bu}$ çalışmada öğrencilerin grafik okuma ve yorumlama düzeylerinin belirlenmesine yönelik hazırlanan etkinlikler araştırmaya katılan öğrencilere uygulanmıştır. Etkinliklerin uygulanmasının ardından, öğrencilerin yorumlarını ayrıntılı inceleyebilmek için birebir görüşmeler yapılmıştır. Çalışmanın veri toplama araçlarını öğrencilerin yazılı etkinlik kâğıtları ve etkinlik tabanlı birebir görüşmelerden elde edilen görüşme metinleri oluşturmaktadır. Çalışmanın bulguları, her bir grafik için grafikleri öğrencilerin kendilerinin yorumlamalarının istendiği açık uçlu olarak hazırlanan soruda, öğrencilerin grafikleri çok düşük düzey, düşük düzey ve orta düzey olarak üç farklı düzeyde veriler arası okuma yaparak yorumladıklarını, fakat yüksek düzeyde veriler arası okuma yaparak yorumlayamadıklarını ortaya koymuştur. Diğer taraftan, elde edilen bulgular verileri grafikten doğrudan okuyarak ve karşılaştırarak cevap verecekleri yapılandırılmış soruları ise öğrencilerin çoğunlukla doğru cevapladıklarını ortaya koymuştur. $\mathrm{Bu}$ çalışma ile matematik öğretmenlerine veri işleme öğrenme alanının öğretiminde, öğrencilerin istatistiksel okuryazarlığını geliştirmelerine yönelik, bu çalışmada yer alan etkinlikler gibi, istatistiksel bilgiyi yorumlayıcı ve eleştirel yönde ele aldıkları etkinliklere yer vermeleri önerilmektedir.

Anahtar Kelimeler: Grafik okuma, grafik yorumlama, istatistiksel grafikler, istatistiksel okuryazarlık, ortaokul öğrencileri.

\section{Suggested APA Citation/Önerilen APA Atıf Biçimi:}

Güler, H. K., \& Didiş Kabar, M. G. (2021). Ortaokul öğrencilerinin istatistiksel grafikleri okuma ve yorumlama düzeylerinin incelenmesi. Cumhuriyet International Journal of Education, 10(1), 23-52. http://dx.doi.org/10.30703/cije.677238

\footnotetext{
* Bu çalışma, Tokat Gaziosmanpaşa Üniversitesinde, 2019 yılında, ikinci yazarın danışmanlığında tamamlanan birinci yazarın yüksek lisans tezinin bir bölümünden olușturulmuștur.

${ }_{1}^{1}$ Öğretmen, Milli Eğitim Bakanlığı, Sivas/Türkiye

Teacher, The Ministry of Education, Sivas/Turkey

e-mail: hatkub93@gmail.com ORCID ID: orcid.org/0000-0003-3980-8851

2 Doç. Dr, Tokat Gaziosmanpaşa Üniversitesi, Matematik ve Fen Eğitimi Bölümü, Tokat/Türkiye

Assoc. Prof. Dr., Tokat Gaziosmanpasa University, Mathematics and Science Education Department ,Tokat/Turkey e-mail: gozde.didis@gop.edu.tr ORCID ID: orcid.org/ 0000-0003-4202-2323
} 


\title{
Investigation of Middle School Students' Statistical Graph s Reading and Interpretation Levels
}

\begin{abstract}
It is emphasized that statistical literacy has an important place in our personal life to be a good consumer, citizen and employee. The ability to read and interpret statistical graphs is an important part of statistical literacy. Students must be able to read and interpret the information presented with the graphs encountering through different media such as newspapers and magazines. This study, carried out as a case study, examined the reading and interpreting graphs levels of five middle school students. This study was conducted during the spring semester of the 2017-2018 academic year in a public middle school located in the district of Sivas. The participants of the study consisted of five ( 4 girls, 1 boy) 7th-grade students. For the purpose of the study, the activities designed by the researchers were implemented to examine the students' levels of graph reading and interpretation. After the activities were implemented, the individual interviews were conducted with five participating students to examine their graph reading and interpretation levels in more detail. The data sources for this study were students' written activity sheets of including reading and interpreting graphs and activity-based individual interviews. The findings of the study revealed that the students interpreted the graphs, where they were asked to interpret the graphs through an open-ended question for each graph, by reading between data at three different levels as very low level, low level and medium level, but they could not read between data at a high level. On the other hand, the findings indicated that the students answered the structured questions accurately that they would answer by reading and comparing the data directly from the graph. To improve students' statistical literacy in teaching data analysis learning area, this study suggests that mathematics teachers should present similar activities included in this study, which students deal with interpreting and critically analyzing statistical information.
\end{abstract}

Keywords: Reading graphs, interpreting graphs, statistical graphs, statistical literacy, middle school students

\section{Giriş}

Günlük yaşamlarında insanlar her gün, gazeteler, broşürler, reklam panoları veya televizyon reklamları gibi birçok yerde istatistiksel bilgilerle karşılaşırlar. İstatistiksel bilgilerin günlük hayatlarında birçok yerde karşılarına çıkması bireyleri iyi bir istatistiksel okuryazar olmaya yönlendirir. İstatistik Eğitiminde Değerlendirme ve Öğretim Kılavuzu'nda [GAISE Raporu] istatistiksel bilgilerin insanların bireysel yaşamlarındaki kararlarına rehberlik etmesine ve vatandaşlar olarak sorumluluklarını yerine getirmesini sağlamasına dikkat çekilmektedir (Franklin vd., 2007). Diğer taraftan, bu kılavuzda iyi bir tüketici, vatandaş ve çalışan olmak için istatistiksel okuryazarlığın bireysel yaşamda önemli bir yeri olduğu vurgulanırken, istatistiksel okuryazar bir bireyin gazetede yer alan bir veriyi yorumlamayı bilmesi ve sunulan istatistiksel iddialar hakkında doğru soruyu sorabilmesi gerektiğine de dikkat çekilmektedir (Franklin vd., 2007).

İstatistiksel okuryazarlığın tek tip ve formel bir tanımı yoktur (Ben-Zvi ve Garfield, 2004). Ben-Zvi ve Garfield (2004) istatistik okuryazarlığın istatistiksel bilgileri veya araştırma sonuçlarını anlamak için verileri organize etme, tabloları oluşturma ve verilerin farklı gösterimleri ile çalışma şeklinde temel ve önemli becerileri içerdiğini belirtmektedir. Gal (2002) ise istatistiksel okuryazarlığı bir modelle açıklamaktadır. Onun modelinde istatistiksel okuryazarlık, okuryazarlık 
becerileri, istatistiksel bilgi, matematiksel bilgi, bağlam bilgisi ve eleştirel sorular olmak üzere beş bilişsel ögeden oluşan bilgi bileşenini ve eleştirel/kritik duruş ve tutum/inanç olmak üzere iki eğilim bileşenini içermektedir. Watson ve Callingham (2003) ise istatistiksel okuryazarlığı "kişiye özgü, informal, tutarsız, tutarl1-kritik olmayan, kritik, kritik-matematiksel" olacak şekilde hiyerarşik altı seviyeli bir yapıda detaylı olarak açıklamıştır.

İstatistiksel düşünme ve istatistiksel okuryazarlı̆̆ın insanların günlük hayatlarında öneminin artırmasıyla birlikte, çeyrek asırdan daha fazla bir süredir, istatistik öğrenimi, veri işleme ve olasılık öğrenme alanlarıyla, okul öncesinden on ikinci sınıfa kadar tüm dünyada matematik öğretiminin temel bir bileşeni haline gelmiştir (Franklin vd., 2007; National Council of Teachers of Mathematics [NCTM], 2000). Benzer şekilde Türkiye'deki güncel matematik öğretimi programında da veri işleme öğrenme alanı aynı oranda önem kazanmıştır. Son on beş yıl içinde gerçekleştirilen program geliştirme çalışmalarının ardından, özellikle de ilkokul, ortaokul ve lise öğreniminde, diğer öğrenme alanları gibi veri işleme öğrenme alanı matematik programlarında önemli bir yer tutmaya başlamıştır (Milli Eğitim Bakanlığ1 [MEB], 2009; 2013 ve 2018). Örneğin, ortaokul matematik öğretim programı kapsamında bakıldığında, istatistik öğretimine 2009 yılı 6-8. sinıflar İlköğretim Matematik Dersi Öğretim Programı'nda Olasılık ve İstatistik öğrenme alanı altında yer verilirken, 2013 ve 2018 yılları Ortaokul Matematik Dersi Öğretim Programı'nda ise Veri İşleme öğrenme alanı altında her sınıf düzeyinde sarmal olarak yer verilmiştir (MEB, 2009; 2013 ve 2018). Yine 2013 ve 2018 yll matematik öğretim programı incelendiğinde, beşinci sınıf kademesindeki öğrencilerden beklenen beceriler veri toplamaya ilişkin araştırma soruları üretmeleri, topladıkları verileri organize edip sıklık tablosu oluşturmaları, sütun grafiği çizebilmeleri biçiminde açıklanmıştır. Altıncı sınıf kademesindeki öğrencilerden beklenen beceriler kapsamında ise beşinci sınıf kademesindeki öğrencilerden beklenen becerilerden farklı olarak iki farklı veri grubuna ilişkin karşılaştırma yapıp yorum yapabilmeleri, merkezi eğilim ölçülerinden aritmetik ortalama ve bir veri grubuna ilişkin açıklığı hesaplayabilmeleri beklenmektedir. Benzer şekilde, yedinci sınıf kademesindeki öğrencilerden beklenen beceriler arasında da çizgi ve daire grafiği oluşturup yorumlayabilmeleri yer almaktadır. Sekizinci sınıf öğrencilerinden beklenen davranışlar ise verilen bilgilere uygun daire, çizgi, sütun grafiği ve histogram oluşturup yorumlama gibi becerileri kazanmalarını kapsamaktadır (MEB, 2013 ve 2018). Sonuç olarak bu becerilere bakıldığında, grafiklerin matematik öğretim programlarında istatistik öğretme ve öğrenme sürecindeki kazanımlarının önemli bir parçasını oluşturduğu da görülmektedir.

İstatistiksel grafikler yaşamın birçok alanında yer aldığı için, toplumda önemli bir rol oynamaktadır (González, Espinel ve Ainley, 2011). Grafikler, verileri kısa ve öz olarak aynı zamanda görsel olarak özetleyen temsillerden biridir (Lacefield, 2009). Grafikler, gazete, dergi ve reklamlarda bulunan metin materyallerini açıklamak, düzenlemek ve özetlemek için yardımcı bir araçtır (Curcio, 1981). Genel olarak kitaplarda ve eğitim yazılımlarında bulunurlar ve öğrencilerin hem fen bilimlerine hem de sosyal bilimlere ait verileri anlamalarına yardım ederler (Shah ve Hoeffner, 2002). Grafikler, istatistiki araştırma sürecinin bir parçası olarak bilgileri anlamlı bir şekilde düzenlemenin bir yolunu gösterirler (Bright ve Friel, 2012). İstatistiksel 
grafikleri anlayabilmek, okuyabilmek ve yorumlayabilmek istatistiksel okuryazarlığın önemli bir parçasını oluşturmaktadır (González, Espinel ve Ainley, 2011; Watson, 2006). Grafiksel formda sunulan verilerin aslına uygun bir şekilde okunabilmesi grafik okuma becerisinin önemli bir parçasıdır (Curcio, 1987). Bu nedenle, öğrencilerin yalnızca okul matematik derslerinde değil, günümüzde gazete ve dergi gibi farklı kanallar aracılığıyla karşılarına çıkan grafikle sunulan bilgileri okuyup yorumlayabilmeleri de önem arz etmektedir. Ayrıca, öğrencilerin okulda öğrendikleri bilgileri günlük hayatlarında karşılarına çıkan durumlara aktarabilmeleri de gerekmektedir. Bununla birlikte bazı durumlarda, grafiklerde gösterilen bilginin anlaşılması öğrenciler için zor olabilmektedir. Öğrenciler özellikle grafikte açıç̧a gösterilmeyen sayısal bilgileri yorumlarken hata yapma eğilimindedirler (Shah ve Hoeffner, 2002).

Uluslararası birçok araştırmada, öğrencilerin grafikleri okuma ve yorumlama becerisine odaklanılarak farklı sınıf düzeyinde öğrenim gören öğrencilerin istatistiksel okuryazarlıkları araştırılmıştır (Aoyama, 2007; Aoyama ve Stephens, 2003; Arteaga, Batanero, Contreras ve Cãnadas, 2015; Bestgen, 1980; Bright ve Friel, 2012; Curcio, 1987; Monteiro ve Ainley, 2007; Sharma, 2005 ve 2013; Swatton ve Taylor, 1994). Farklı sınıf düzeylerinde öğrenim gören öğrencilerin grafik okuma ve grafik yorumlama düzeyleri ile ilgili yapılan birçok uluslararası çalışma, öğrencilerin grafik yorumlamayla ilgili olarak zorluklar yaşadıklarını ortaya koymaktadır. Bu çalışmalar ortak olarak grafiklerde sunulan verileri öğrencilerin okuyabildiklerini ortaya koyarken, öğrencilerin genellikle grafikteki veriler arası ilişkileri okumada, verilere dayalı tahmin yapmada ve çıkarım yapmada zorluklar yaşadıklarını göstermektedir (Aoyama, 2007; Curcio, 1987; Hafiyusholeh, Budayasa ve Siswono, 2018; Sharma, 2005). Bu araştırmalardan Curcio (1987) tarafından yapılan çalışmada, dördüncü ve yedinci sınıf öğrencilerin grafik anlamalarına yönelik performanslarına odaklanılmıştır. Çalışmanın verileri, (1) veriyi, başlığı ve eksenleri doğrudan okumay1 gerektiren (reading the data), (2) matematiksel kavram ve becerilerin kullanılmasını ve karşılaştırılmasını, yani veriler arası okumayı gerektiren (reading between the data) ve (3) genişletme, tahmin ve çlkarım yapmayı, verilerin ötesi okumayı (reading beyond the data) gerektiren, öğrencilerin grafik kavramalarını üç farklı boyutta ele alacak şekilde tasarlanan sorular üzerinden elde edilmiştir. Çalışmanın sonucunda da, öğrencilerin grafikleri anlamaları için gerekli olan şemaları oluşturmak ve genişletmek için grafik etkinliklerine katılmaları gerektiği açıklanmıştır. Sharma'nın (2005) çalışmasında ise, lise öğrencilerinin, grafiksel gösterimlerle ilgili istatistiksel düşünme ve anlamaları, tablo ve grafikler içeren açık uçlu etkinlikler ve bu etkinliklere dayalı görüşmeler aracılığıyla incelenmiştir. Çalışmanın sonucunda, öğrencilerin sütun grafiklerini okuyabildikleri fakat tablo ve grafik verilerine dayalı çıkarım yapmakta zorlandikları ortaya koyulmuştur. Aoyama (2007, s.300) tarafından yapılan araştırmada, Japonya' da farklı sınıf düzeylerinde öğrenim gören öğrencilerle çalışılarak, öğrencilerin grafik yorumlama düzeylerinin belirlenmesi amaçlanmıştır. Bu çalışmada, Watson ve Callingham'ın (2003) istatistiksel okuryazarlığa yönelik sınıflandırması ile ilişkili olarak, öğrencilerin grafik yorumlama süreçleri "Hipotez ve modelleme", "Eleştirel", "Akılc1/Aslına Uygun", "Basit grafik okuma" ve "Kişiye özgü okuma" olarak hiyerarşik olacak şekilde beş seviyede tanımlanmıştır. 
Türkiye'de de matematik öğretiminde istatistik öğrenimine verilen öneminde artmasıyla, son yıllarda farklı sınıf seviyesindeki öğrencilerin istatistiksel süreçlerini, istatistiksel okuryazarlıklarını, istatistiksel okuryazarlığın matematik öğretim programındaki yerini, öğrencilerin grafik okuma ve çizme becerilerini ve zorluklarını ve öğretmen adaylarının istatistik öğretimine yönelik alan/pedagojik alan bilgilerini nitel ve nicel araştırma yöntemleri kullanarak inceleyen çalışmaların yapıldı ̆̆ görülmektedir (Ev-Çimen ve Yıldız, 2018; Güven, Öztürk ve Özmen, 2015; Erbilgin, Arıkan ve Yabanl1, 2015; Özmen ve Baki, 2019; Karatoprak, Karagöz-Akar ve Börkan, 2017; Koparan ve Güven, 2013 ve 2014; Kuş ve Çakıroğlu, 2020; Sezgin-Memnun, 2013; Yayla ve Özsevgeç, 2015; Yılmaz ve Ay, 2016). Bu çalışmalarda farklı sınıf düzeylerindeki öğrencilerin istatistiksel düşünme düzeyleri, istatistiksel okuryazarlık düzeyleri ya da istatistiksel sürecin bir parçası olan grafik çizme, okuma veya yorumlama, ortalama, değişim kavramları süreçleri hakkında bilgilendirme yapılmıştır. Örneğin, Koparan ve Güven (2013), 6, 7 ve 8. sınıf öğrencilerinin istatistik öğrenme alanı ve kazanımları doğrultusunda hazırlanmış yirmi altı soruya verdikleri cevapları inceleyerek istatistiksel düşünme modeli çerçevesinde istatistiksel düşünme seviyelerini incelemiştir. Bu çalışmanın bulguları ortaokul öğrencilerinin istatistiksel verilerin tanımlanmasında üst seviyede olmalarına rağmen, istatistiksel verilerin organize edilmesi, indirgenmesi, veri gösterimi, verinin analiz edilmesi ve yorumlanmasında düşük düzeyde olduklarını göstermiştir. Diğer taraftan, bu çalışmalardan öğrencilerin grafik okuma ve yorumlama düzeylerini inceleyen çalışmaların ise özellikle çizgi grafiğini okuma ve yorumlama ile ilgili (Erbilgin, Arıkan ve Yabanlı, 2015; Sezgin-Memnun, 2013; Yayla ve Özsevgeç, 2015) olduğu görülmektedir. Sezgin-Memnun (2013) çalışmasında yedinci sınıf öğrencilerinin verilen çizgi grafiğini okuyabilme ve verilere uygun çizgi grafiği çizebilme becerilerinin matematik dersi başarısına göre nasıl bir değişim gösterdiğini incelemiştir. Sezgin-Memnun'un (2013) bulguları öğrencilerin çizgi grafiği okumada ve grafiğe bağlı olarak verilen soruları çözmede zorlanmadıklarını ancak büyük çoğunluğun çizgi grafiği oluşturmada yeterli beceriye sahip olamadıklarını göstermiştir. Yayla ve Özsevgeç (2015) de çalışmasında 93 ortaokul öğrencisinin çizgi grafiği çizme ve yorumlama becerilerini sınıf düzeylerine göre incelemişlerdir. Yayla ve Özsevgeç'in (2015) bulguları yedinci ve sekizinci sınıf öğrencilerin çizgi grafiği çizme ve okuma becerileri arasında çok fark olmadığını, altıncı sınıf öğrencilerinin çizgi grafiği çizme ve okuma becerilerinin yedinci ve sekizinci sınıf öğrencilere göre daha düşük seviyede olduğunu göstermektedir. Aynı zamanda bulgular öğrencilerin çizgi grafiği oluşturmada, çizgi grafiklerini yorumlamaya göre daha çok zorlandıklarını ortaya koymuştur. Yılmaz ve Ay'ın (2016) ise 8. sınıf öğrencilerinin histograma ilişkin bilgi ve becerilerini inceleyen çalışmasında, öğrencilerin histogramı yorumlayabilmeleri ile bulguları, çalışmaya katılan öğrencilerden ikisinin dışında diğerlerinin grafiği yorumlamak yerine grafiği okuma eğilimi içinde olduklarını göstermiş ve öğrencilerin histogramı yorumlama eksikliklerinin olduğunu ortaya koymuştur.

Bireylerin sahip olması gereken istatistiksel düşünmenin ve istatistiksel okuryazarlık becerilerinin oldukça önemsendiği çağımızda, farklı eğitim ortamlarında ve sosyo-ekonomik şartlar altında öğrenim gören, farklı akademik başarı ve ilgi düzeylerine sahip olan öğrencilerin istatistiksel sürece ne kadar dâhil 
olabildiklerini bilmek önemlidir. Bu sebeplerle, öğrencilerin farklı grafik türlerinde de grafik okuma ve yorumlama düzeylerini inceleyen çalışmaların artması önem arz etmektedir. Bu çalışmada, ortaokul yedinci sınıf öğrencilerinin istatistiksel sürecin basamaklarından verilerin yorumlanması süreci ile ilişkili olan sütun ve daire grafikleri ile gösterilen sonuçların okunması ve yorumlanması düzeylerinin incelenmesi amaçlanmıştır. Bu amaçla, bu çalışmada aşağıda yer verilen araştırma sorusuna cevap aranmıştır: nedir?"

"Ortaokul 7. sinı öğrencilerinin grafik verilerini okuma ve yorumlama düzeyleri

$\mathrm{Bu}$ çalışma, matematik öğretmenlerini öğrencilerin grafikleri yorumlama süreçleri ile ilgili istatistiksel okuryazarlıkları hakkında bilgilendirerek, matematik öğretmenlerine veri işleme öğrenme alanı kazanımlarını öğretirken nelere dikkat etmesi gerektiği konusunda ışık tutacaktır. Aynı zamanda, bu çalışmanın bulgularının istatistik öğrenimi ve öğretimine yönelik olarak yapılacak olan çalışmalara katkı sağlayacağı, öğrencilerin istatistiksel süreçleri üzerinde çalışacak araştırmacılara yol göstereceği düşünülmektedir.

\section{Yöntem}

Bu çalışmada ortaokul yedinci sınıf öğrencilerinin istatistiksel grafikler ile gösterilen sonuçları okuma ve yorumlama düzeylerinin detaylı bir biçimde incelenmesi amaçlandığından, çalışma nitel araştırma yöntemlerinden durum (örnek olay) çalışması kullanılarak gerçekleştirilmiştir.

\section{Çalışma Grubu}

Bu çalışma 2017-2018 eğitim-öğretim yılının bahar döneminde, Sivas ilinin Hafik ilçesinde yer alan bir devlet ortaokulunda gerçekleştirilmiştir. Çalışmanın katılımcılarını bu devlet ortaokulunun, yedinci sınıfında öğrenim gören beş (4 kız, 1 erkek) öğrenci oluşturmaktadır. Çalışmanın gerçekleştiği okulun ve sınıfın belirlenmesinde, kolay ulaşılabilir durum örneklemesi kullanılmıştır (Yıldırım ve Şimşek, 2006, s.123). Çalışmanın katılımcılarının yedinci sınıf öğrencilerden seçilmesinin nedeni, yedinci sınıf öğrencilerinin ortaokul (5-8) öğretim programında "Veri İşleme" alanına yönelik kazanımları tamamlamış olup, histogram dışında, diğer üç grafik türü olan sütun, çizgi ve daire grafiklerini öğrenmiş olmalarıdır. Diğer taraftan, veri işleme alanının tüm kazanımlarını tamamlamış olan 8. sınıf öğrencileri ile çalışılmama nedeni ise çalışmanın gerçekleştirildiği dönemde, 8. sınıf öğrencilerinin sınava (Sinavla Öğrenci Alacak Ortaöğretim Kurumlarına İlişkin Merkezi Sınav) girecek olmaları, sınava hazırlık süreçleri ve sınav kaygısı sebebiyle, yedinci sınıf öğrencilerinin daha ulaşılabilir olması olmuştur. Çalışmanın katılımcıları olan beş öğrenci, yedinci sınıf matematik dersini alan, 6 kız 9 erkek öğrenci olmak üzere toplamda 15 öğrenci arasından seçilmiştir. Araştırmaya katılan beş öğrencinin seçiminde ise amaçlı örnekleme yöntemlerinden olan ölçüt örnekleme yöntemi kullanılmıştır (Yıldırım ve Şimşek, 2006, s.112). Ölçüt örneklemede araştırmacı, çalışma öncesinde belirlenen bir ölçüte göre seçim yapabilir. Seçtiği örneklem araştırmanın amacına uygun ve araştırmanın soruları için istenen verileri sağlayabilecek bireylerden oluşmaktadır (Yıldırım ve Şimşek, 2006, s.112). Bu araştırmada, öğrencilerin matematik ön bilgi eksikliklerinin, grafiklerde sunulan matematiksel bilgi ve düşünceleri anlama ve yorumlamalarında engelleyici faktör 
olmaması açısından, araştırmaya katılan öğrenciler seçilirken, matematik dersine ön yargısı olmaması ve ders başarı düzeylerinin yüksek olması ölçüt olarak belirlenmiştir. Bu sebeple, genel akademik başarısı, 5, 6 ve 7. sınıf birinci dönem matematik dersi not ortalamaları en yüksek olan ve çalışmaya katılmaya gönüllü olan öğrenciler araştırmanın katılımcısı olarak belirlenmiştir. Araştırmada öğrencilerin gerçek isimleri kullanılmamış olup, araştırmacı tarafından farklı isimler verilmiştir. Çalışmaya katılan öğrenciler ile ilgili bilgiler Tablo 1'de sunulmaktadır.

Tablo 1

Araştırmaya Katılan Öğrenciler ile İlgili Bilgiler

\begin{tabular}{lcccc}
\hline Öğrenciler & Cinsiyet & Yaş & $\begin{array}{c}\text { Genel Başarı } \\
\text { Ortalamaları }\end{array}$ & $\begin{array}{c}\text { Matematik Başarı } \\
\text { Ortalamaları }\end{array}$ \\
\hline Buse & $\mathrm{K} 1 \mathrm{z}$ & 13 & 83,98 & 80,08 \\
Deniz & $\mathrm{K} 1 \mathrm{z}$ & 13 & 90,43 & 99,59 \\
Ömer & Erkek & 13 & 92,24 & 98,26 \\
Sevgi & $\mathrm{K} 1 \mathrm{z}$ & 13 & 90,49 & 84,58 \\
İlkay & $\mathrm{K}$ iz & 13 & 94,99 & 97,37 \\
\hline
\end{tabular}

\section{Veri Toplama Araçları}

$\mathrm{Bu}$ çalışmanın veri toplama araçlarını öğrencilerin yazılı etkinlik kâğıtları ve sınıfta yapılan etkinliklerden sonra uygulanan birebir görüşmeler oluşturmaktadır.

Etkinlik kâğıtları. Çalışmanın amacı doğrultusunda, öğrencilerin grafik okuma ve yorumlama düzeylerinin incelenmesi amacıyla kullanılan etkinliklerden dördü bu çalışmanın araştırmacıları tarafından geliştirilmiştir. Grafik yorumlama etkinlikleri geliştirilmeden önce, alan yazındaki ilgili çalışmalarda (Aoyama, 2007; Sharma, 2005 ve 2013), ortaokul matematik kitaplarında ve matematik uygulamaları kitaplarında yer alan ilgili sorular ve 2012-2018 yılları arasındaki Türkiye İstatistik Kurumu (TÜİK) web sitesinde (www.tuik.gov.tr) yer alan ve grafik olarak sunulan haberler detaylı olarak incelenmiştir. Grafiklerin öğrencilerin gazete, dergi veya web ortamında her zaman karşılarına çıkacak gerçekçi grafikler olması durumu da dikkate alınarak, öğrencinin günlük yaşamıyla bağdaştırabileceği türde gerçekçi veriler sunabilmek için etkinliklerdeki grafiklerin hazırlanmasında TÜíK web sitesinde yer alan ve grafik olarak sunulan bilgilerden yararlanılmıştır. İlk olarak TÜİK web sitesinde (örneğin, TÜİK, 2016a; 2016b; 2017a ve 2017b) yer alan grafiklerle sunulan bilgilere ait grafik verilerinden yararlanılarak, sütun, daire ve çizgi grafik türlerini içeren, grafikler oluşturulmuştur. Hazırlanan her bir grafik için araştırmacılar tarafından problem durumları yazılmış ve öğrencilerin verileri okuyarak yorumlamalarını gerektirecek 3 ila 5 arasında değişen soru hazırlanmış ve toplamda altı etkinlik geliştirilmiştir. Şekil 2'de örnek olarak sunulduğu gibi, hazırlanan tüm etkinlikler için birinci alt soru "Bu grafiği inceleyiniz. Siz bu grafiği nasıl yorumlarsınız? Yorumlarınızı aşağıda verilen boşluğa yazınız." şeklinde ortak soru olacak şekilde hazırlanmıştır. Bu soru öğrencilerin sadece ders ortamında değil, günlük hayatlarında böyle bir grafikle karşılaştıklarında, bu grafiği nasıl yorumladıklarını incelemek amacıyla tasarlanmıştır. Bu sebeple, bu soru grafiğin hemen altında ve etkinlik kâğıdının ilk sayfasında sunulmuştur. Bu grafiğe yönelik hazırlanan diğer alt sorular ise, cevabın açıkça grafiklerde yer aldığı, öğrencileri grafik verilerini 
doğrudan okuyarak ve değerleri karşılaştırarak cevaplayabileceği sorular olarak hazırlanmıştır. Öğrencilerin birinci soruda sadece grafiği görerek yorumlama sürecini etkilemeden kendi yorumunu yapabilmesi açısından, diğer alt sorular etkinlik kâğıdının ikinci sayfasında, yani ayrı bir sayfada verilmiştir. Diğger taraftan, hazırlanan bu etkinliklere ek olarak, sütun grafiği ve daire grafiğini bir arada yorumlamayı içeren bir soru da 7. Sınıf Matematik Uygulamaları ders kitabından (Aydın, Özdoğan ve Koçak, 2017, s.58) seçilerek etkinlikler arasına eklenmiştir. Toplamda bu araştırma kapsamında sütun, daire ve çizgi grafiklerini içeren yedi etkinlik hazırlanmıştır.

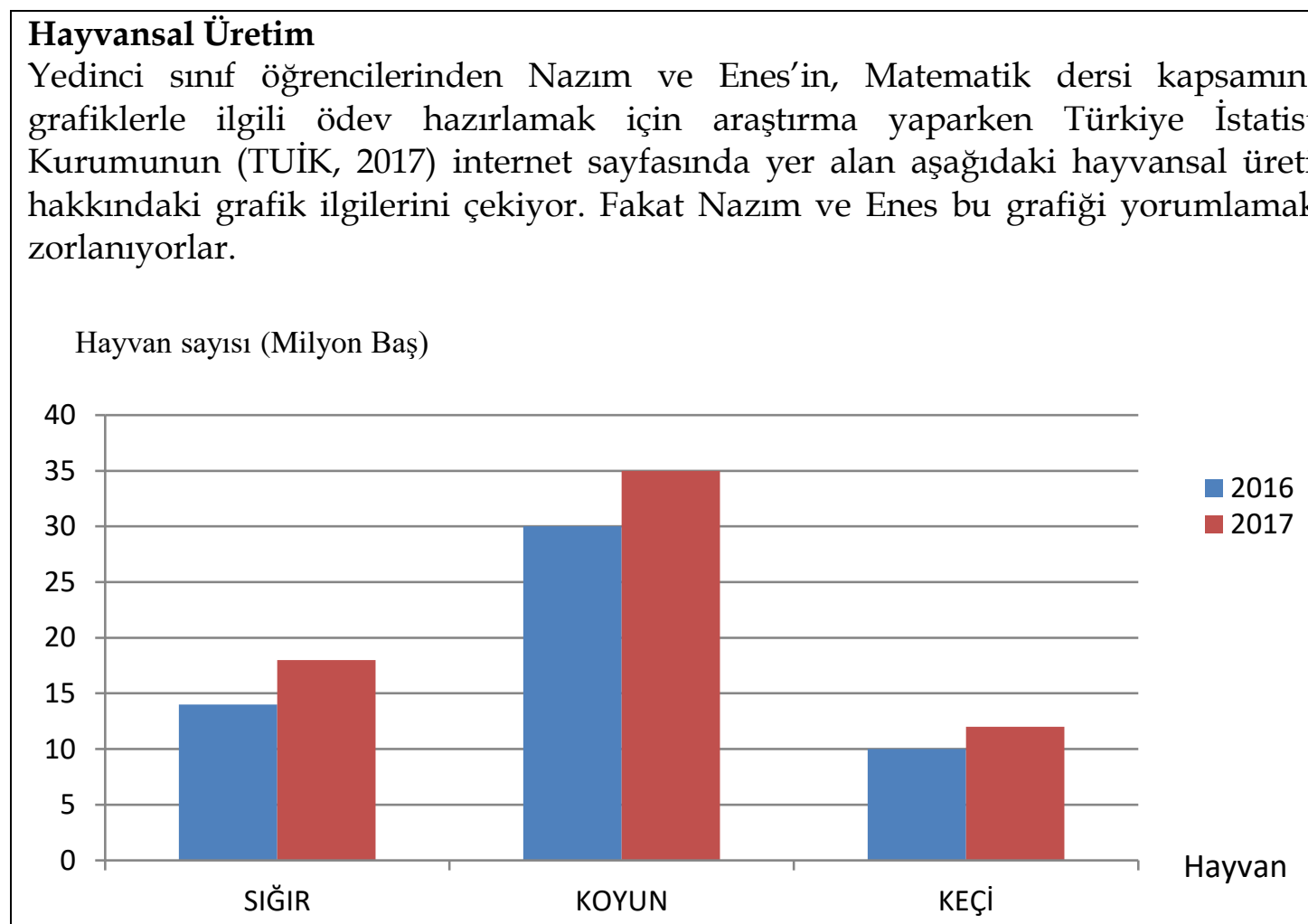

1. Bu grafiği inceleyiniz. Nazım ve Enes'e yardımcı olmak için, siz bu grafiği nasıl yorumlarsınız. Yorumlarınızı aşağıda verilen boşluğa yazınız.

2. Hangi hayvan sayısındaki artış bir önceki yıla göre en fazla olmuştur? Cevabınızı gerekçeleri ile açıklayınız.

3. Büyük baş hayvanlardan olan sığır sayısı, 2017 yılında 2016 yılına göre nasıl değişmiştir? Cevabınızı gerekçeleri ile açıklayınız.

Şekil 2. "Hayvansal Üretim" adlı etkinlik

Hazırlanan etkinliklerin öğrencilerin seviyesine ve yedinci sınıf kazanımlarına uygunluğuna dikkat edilmiştir. Grafik yorumlama ile ilgili tüm etkinlikler hazırlandıktan sonra ilk olarak ortaokulda öğretmenlik yapan üç matematik öğretmeni ve biri matematik eğitiminde istatistik öğrenimi üzerinde çalışmaları olan, diğeri matematik öğretimi alanında uzman iki matematik eğitimcisinden, hazırlanan etkinliklerin "öğrenci seviyesine uygunluğu, amaca uygunluğu, anlaşılırlığı, dil ve anlatımı" açısından, uzman görüşleri alınmıştır. Alınan uzman görüşleri doğrultusunda, etkinliklerin bağlamında, dil ve anlatımında düzeltmeler yapılmıştır. 
Gerekli düzeltmeler yapılıp etkinlikler hazırlandıktan sonra, çalışmanın yapıldığı ilçede bulunan iki farklı ortaokulun sekizinci sınıf öğrencileri ile pilot uygulama yapılmıştır. Pilot uygulamaların yapıldığı süreçte yedinci sınıf öğrencileri veri işleme öğrenme alanına ait kazanımların henüz tamamını öğrenmediği için, pilot uygulamalarda çalışma grubu olarak çalışmanın amacı kapsamında kullanılan tüm grafik türlerini öğrenmiş olan sekizinci sınıf öğrencileri tercih edilmiştir. Yapılan pilot uygulama sonucunda hazırlanan benzer şekilde tasarlanmış çizgi grafiği içeren iki etkinlikte yer alan grafiklerin anlaşılması ile ilgili gözlemlenen problemler sonucunda, öğrenci seviyesi ile uyumlu olmadığına karar verilerek ikisinin uygulanmasından vazgeçilmiştir.

Yapılan bu çalışmaların ardından, hazırlanan etkinliklerden sütun ve daire grafiği içeren toplam beş etkinliğin öğrencilere uygulanmasına karar verilmiştir. Aynı zamanda iki okulda yapılan pilot uygulamalarda öğrencilerin üç etkinliği yaklaşık olarak 40-50 dakika arasında yaptıkları ve beş etkinliğin aynı anda uygulanmasının süre açısından uzun olduğu gözlemlenmiştir. Öğrencilerin dikkatinin dağılarak performanslarını etkilemesini önlemek amacıyla etkinliklerin, iki etkinlik ve üç etkinlik olacak şekilde iki aşamada birer hafta arayla uygulanması kararı alınmıştır.

Etkinlikler, okul ders saatlerinin hemen bitimini takip ederek başlayan matematik kurs saatlerinde uygulanmıştır. Öğrenciler tüm uygulamalarda, etkinlikler üzerinde bireysel çalışmışlardır. Hazırlanan etkinlikler, pilot uygulama sonucunda planlandığı gibi iki aşama halinde uygulanmıştır. Birinci aşamada, iki etkinlik, ikinci aşamada diğer üç etkinlik uygulanmıştır. İlk aşamada uygulanan iki etkinliğin uygulama süresi yaklaşık olarak 40 dakika, ikinci aşama da uygulanan diğer üç etkinliğin uygulama süresi ise 50-60 dakika sürmüştür.

Görüşmeler. Etkinlikler uygulandıktan sonra uygulamanın yapıldığı haftalar içerisinde öğrencilerin yorumlarını daha ayrıntılı inceleyebilmek için çalışmanın katılımcıları olarak belirlenen beş öğrenci ile yarı yapılandırılmış birebir görüşmeler yapılmıştır. Bu sebeple, her bir öğrenci ile iki kez görüşme yapılmıştır. Etkinliklerine ait görüşmelerde öğrencilere "Verilen grafiği nasıl yorumladın (yorumlar mısın)? Grafik ne anlatıyor/neyi açıklıyor? Neden?, 2015 ve 2016 yıllar arasında kütüphaneden yararlanan kişi sayısının arttı̆̆ını/azaldığını nasıl belirledin? Açıklar mısın?" şeklinde etkinlik kâğıtlarında bulunan sorulara dayalı sorular sorularak, yazılı açıklamalarını detaylandırabilmeleri için fırsat tanınmıştır. Bu görüşmeler ise yaklaşık olarak yirmi dakika sürmüştür. Öğrencilerle yapılan tüm görüşmeler video ve ses kaydı altına alınmıştır. Video ve ses kayıtları için öğrenci velilerinden imzalı veli izin belgesi alınmıştır. Görüşmeler sırasında öğrencilerin rahat edebilecekleri samimi bir ortam oluşturulmuştur.

\section{Verilerin Analizi}

Verilerin analizi iki aşamalı olarak yapılmıştır. Verilerin analizinde içerik analizi yöntemi kullanılmışır. Kategorilerin belirlenmesinde alan yazındaki ilgili çalışmalarda sunulan Aoyama (2007) ve Curciónun (1987) tanımladığ1 kategorilerden yararlanılmıştır. $\mathrm{Bu}$ çalışmada kullanılan etkinliklerin amacı düşünülerek, ilk olarak bu araştırmacılara ait kategorilerden, "Kişiye Özgü Okuma" (Aoyama, 2007), "Verileri Okuma" ve "Veriler Arası Okuma" (Curcio, 1987) kategorileri ve ilgili açılamaları belirlenmiştir. Daha sonra, öğrencilerin yazılı 
etkinlik kâğıdında yaptıkları grafik okuma ve yorumlamaları ile ilgili veriler ve görüşmeler esnasındaki veriler bir arada incelenerek belirlenen kategoriler altında ön analiz yapılmıştır. Bununla birlikte, verilerin ön analizi sürecinde, bu kategorilerin detaylandırılmasına gerek duyulmuş ve Tablo 2' de sunulan kategori ve kod listesi oluşturulmuştur. Verilerin analizinin birinci aşamasında, her bir etkinliğe ait grafikte ortak soru olarak sunulan "Bu grafiği inceleyiniz. Siz bu grafiği nasıl yorumlarsinız? Yorumlarınızı aşağıda verilen boşluğa yazınız." sorusuna her bir öğrencinin verdiği cevap analiz edilmiştir. Veriler bu listede yer alan veriler arası okuma ve kişiye özgü okuma kategorisine göre kodlanmıştır. Verilerin analizinin ikinci aşamasında her bir etkinliğe ait grafikte yer alan diğer alt soruların analizi yapılmıştır. Bu alt sorulara ait veriler ise listede yer alan veriyi okuma ve veriyi okuyamama kategorisine göre kodlanmıştır. Her bir öğrencinin her bir etkinlikte alt sorulara vermiş olduğu cevaplar tek tek incelenerek, doğru, yanlış, kısmi doğru ve boş olarak kodlanmıştır. Öğrencilerin verilere ait sayısal değerleri doğru okuyarak, soruda istenilenleri tam olarak açıkladığı cevaplar doğru cevap olarak, öğrencilerin verilere ait sayısal değerleri yaklaşık veya yanlış okuyarak ve yanlış hesaplamalar yaparak açıklamalar yapması ise yanlış cevap olarak kodlanmıştır. Diğer taraftan, öğrencilerin grafikte sunulan sayısal verilere dayalı olmadan genel cevaplar vermesi ile sorunun istediği tam açıklayıcı cevabı vermediği doğru cevaplar kısmi doğru cevap olarak kodlanmiştır.

$\mathrm{Bu}$ çalışmanın geçerliliği, katılımcılarla uzun süreli etkileşim, derin odaklı veri toplama ve çeşitleme yöntemleri ile sağlanmıştır. Öğrencilerin yazılı etkinlik kâğıtları ve birebir görüşmeler kullanılarak, yani farklı veri kaynaklarını çeşitlendirilerek derin odaklı veri toplanmıştır. Aynı zamanda aynı öğrenci ile birden fazla yapılan görüşmelerde araştırmacı ile veri kaynağı arasında uzun süreli etkileşim sağlanmıştır. Bu araştırmanın güvenirliğini sağlamak amacıyla her bir öğrenciyle etkinlikler sonrası yapılan birebir görüşmeler ses ve video kaydı altına alınmıştır. Diğer taraftan, öğrencilerin etkinlik kâğıtlarından ve birebir görüşmelerden elde edilen beş öğrenciye ait tüm veriler bu çalışmanın araştırmacıları tarafından bağımsız olarak kodlanmış ve araştırmacılar arasındaki kod uyumu Miles ve Huberman'ın (1994) uyuşum yüzdesi formülü kullanılarak hesaplanmıştır. Araştırmacıların kodlamaları arasında uyuşum yüzdesi \%80 olarak elde edilmiştir. Araştırmacılar arasındaki kodlama farklılıkları öğrencilerin bazı grafiklerde veriler arası okuma düzeylerinin farklı şekilde kodlanmasında ortaya çıkmıştır. Örneğin, bir araştırmacı "çok düşük düzey olarak" kodlarken, diğer araştırmacı "düşük düzey" olarak kodlamıştır. Araştırmacılar bir araya gelerek, kodlamalarda çıkan farklılıkları, Tablo 2'deki tanımlamaları kapsamında tekrar değerlendirerek fikir birliğine varmışlardır.

Tablo 2

Kod ve Kategori Listesi

\begin{tabular}{cccl}
\hline Kategoriler & $\begin{array}{c}\text { Alt } \\
\text { Kategoriler }\end{array}$ & \multicolumn{1}{c}{ Kodlar } & Kategorilerin Açıklaması \\
\hline $\begin{array}{c}\text { Veriyi } \\
\text { Okuyamama } \\
\text { okuma veya } \\
\text { verileri } \\
\text { okuyamama }\end{array}$ & $\bullet \begin{array}{l}\text { Sayısal verileri/değerleri } \\
\text { yanlış okuma } \\
\text { Sayısal verileri/değerleri } \\
\text { okuyamama }\end{array}$ & $\begin{array}{l}\text { Cevabın açıça ve direkt } \\
\text { olarak grafikte bulunduğu } \\
\text { bilgileri okuyamama veya } \\
\text { değerlerini yanlış okuma. }\end{array}$ \\
\hline
\end{tabular}




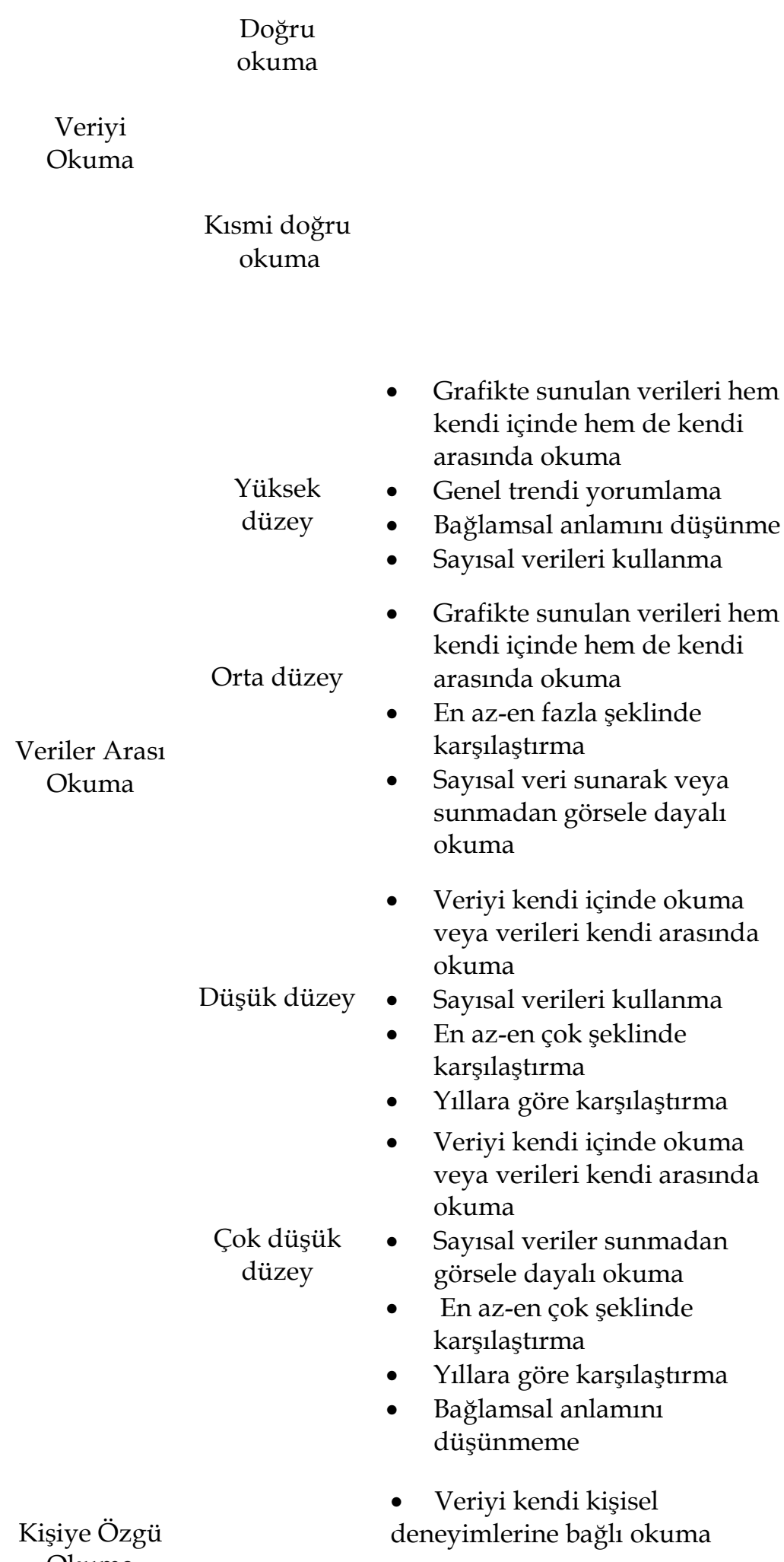

Cevabın açıç̧a ve direkt olarak grafikte bulunduğu bilgileri doğru okuma ve soruya tam doğru açılayıcı cevap verme

Cevabın açıkça ve direkt olarak grafikte bulunduğu bilgileri tam doğru okuyamama ve soruya genel cevap verme

Cevabın açıkça ve direkt olarak grafikte bulunduğu bilgileri okuyarak, grafikte sunulan verileri hem kendi içinde hem de kendi arasında karşılaştırarak yorumlama
Kendine özgü, kendi deneyimlerine bağlı yorumlama veya bağlamsal anlamını düşünmeme 


\section{Bulgular}

Veri analizi kısmında açıklandığ1 gibi her bir etkinliğe ait grafikte ortak soruya her bir öğrencinin verdiği cevap Tablo 2'de yer alan veriler arası okuma ve kişiye özgü okuma kategorisi üzerinden analiz edilmiş ve yapılan analiz sonuçları da Tablo 3 'te sunulmuştur. Tablo 3'te sunulduğu gibi, öğrencilerin yazılı etkinlik kâğıtlarının her birinde ortak soru olan birinci soruya ait yazılı açıklamalarının ve bu soru için görüşmeler sırasında yapmış oldukları açıklamalarının analizi, öğrencilerin sunulan grafikleri, çok düşük düzey, düşük düzey ve orta düzeyde veriler arası okuyarak yorumladıklarını ortaya koymuştur. Diğer taraftan bir öğrenci (Buse) bir etkinlikte sunulan grafiği, diğer bir öğrenci (Ömer) de iki etkinlikte sunulan grafikleri kişiye özgü okuyarak yorumlama eğilimi göstermiştir.

Tablo 3

Öğrencilerin Etkinliklere Göre 1. Soru için Veriler Arası Okuyarak Grafik Yorumlama Düzeyleri

\begin{tabular}{|c|c|c|c|c|c|}
\hline $\begin{array}{l}\text { Etkinlikler } \\
\text { Öğrenciler }\end{array}$ & $\begin{array}{c}\text { Hayvansal } \\
\text { Üretim }\end{array}$ & $\begin{array}{l}\text { Gazete } \\
\text { ve } \\
\text { Dergi }\end{array}$ & $\begin{array}{c}\text { Enerji } \\
\text { Kaynakları }\end{array}$ & Kütüphane & $\begin{array}{c}\text { İhraç Miktarı } \\
\text { ve İhraç } \\
\text { Ürünleri }\end{array}$ \\
\hline Buse & Düşük düzey & Orta düzey & Orta düzey & Çok düşük düzey & $\begin{array}{l}\text { Çok düşük } \\
\text { düzey }\end{array}$ \\
\hline Deniz & $\begin{array}{l}\text { Çok düşük } \\
\text { düzey }\end{array}$ & $\begin{array}{l}\text { Düşükk } \\
\text { düzey }\end{array}$ & Düşük düzey & Çok düşük düzey & $\begin{array}{l}\text { Çok düşüuk } \\
\text { düzey }\end{array}$ \\
\hline Ömer & Orta düzey & $\begin{array}{l}\text { Çok düşük } \\
\text { düzey }\end{array}$ & $\begin{array}{l}\text { Çok düşük } \\
\text { düzey }\end{array}$ & Çok düşük düzey & $\begin{array}{l}\text { Çok düşük } \\
\text { düzey }\end{array}$ \\
\hline Sevgi & Düşük düzey & $\begin{array}{l}\text { Çok düşük } \\
\text { düzey }\end{array}$ & Orta düzey & $\begin{array}{l}\text { Veriler aras1 } \\
\text { okuma yok }\end{array}$ & $\begin{array}{l}\text { Veriler aras1 } \\
\text { okuma yok }\end{array}$ \\
\hline İlkay & Orta düzey & $\begin{array}{l}\text { Çok düşük } \\
\text { düzey }\end{array}$ & Düşük düzey & Düşük düzey & Düşük düzey \\
\hline
\end{tabular}

Diğer taraftan, öğrencilerin yazılı etkinlik kâğıtlarında diğer sorulara ait yazılı cevaplarının ve bu sorular için görüşmeler sırasında yapmış oldukları açıklamalarının analizi, Tablo 2'de yer alan veriyi okuma ve veriyi okuyamama kategorilerine göre analiz edilmiş ve analiz sonuçları Tablo $4^{\prime}$ te sunulmuştur. Tablo 4'te sunulduğu gibi öğrencilerin bu sorulara çoğunlukla doğru cevap vermiş oldukları görülmüştür. Diğer taraftan "İhraç Miktarı ve İhraç Ürünleri” adlı etkinliğin dördüncü alt sorusuna bir öğrencinin cevap veremediği, dört öğrencinin ise yanlış cevap verdiği görülmüştür. 
Tablo 4

Öğrencilerin Etkinliklere Göre Alt Sorulara Verdikleri Doğru, Yanlış, Kısmi Doğru Cevaplar*

\begin{tabular}{ccccccccccccccccc}
\hline & $\begin{array}{c}\text { Hayvansal } \\
\text { Üretim }\end{array}$ & \multicolumn{4}{c}{$\begin{array}{c}\text { Gazete ve } \\
\text { Dergi }\end{array}$} & \multicolumn{3}{c}{$\begin{array}{c}\text { Enerji } \\
\text { Kaynaklar1 }\end{array}$} & \multicolumn{3}{c}{ Kütüphane } & \multicolumn{3}{c}{$\begin{array}{c}\text { Ihhraç Miktarı ve } \\
\text { İhraç Ürünleri }\end{array}$} \\
\hline & Soru2(S2) & S3 & S2 & S3 & S4 & S2 & S3 & S2 & S3 & S4 & S5 & S2 & S3 & S4 \\
\hline Buse & + & + & + & + & - & + & + & + & x & - & - & + & + & boş \\
Deniz & - & + & + & + & x & + & + & + & + & + & + & + & + & - \\
Ömer & + & + & + & + & - & + & + & + & + & - & + & + & + & - \\
Sevgi & + & + & + & + & + & + & + & + & + & + & + & + & + & - \\
Illkay & + & + & - & + & + & + & + & + & + & + & + & + & + & + \\
\hline
\end{tabular}

* "+" sembolü öğrencinin cevabının Doğru olduğunu; " $x$ " sembolü öğrencinin cevabinın Kısmi Doğru olduğunu, "-" sembolü öğrencinin cevabinın Yanlı̧̧ olduğunu göstermektedir.

Buse'nin grafik okuma ve yorumlama süreci. Tablo 3'te sunulduğ gibi, Buse iki etkinlikte çok düşük düzeyde veriler arası okuma yaparak, bir etkinlikte düşük düzeyde veriler arası okuma yaparak, iki etkinlikte de orta düzeyde veriler arası okuma yaparak, grafikleri yorumlamıştır. Buse'nin çok düşük düzeyde veriler arası okuma yaptığı Kütüphane etkinliğinde aynı zamanda kişiye özgü yorumda yapmış olduğu görülmüştür. Genel itibariyle, Buse'nin veriler arası okuma yaparak grafikleri yorumlama düzeyi, çok düşük düzey ile orta düzey arasında değişmiştir.

Buse'nin, "Gazete ve Dergi" etkinliğinde, sütun grafiğinde sunulan verileri nasıl okuyup yorumladığı Şekil 3'te sunulmuştur. Buse'nin bu etkinliğe ait grafiği veriler arası okuma yaparak grafiği yorumlama düzeyi orta düzeydir. Buse'nin yazılı açıklamalarında da görüldüğü gibi, Buse grafikte verilen gazete ve dergi satış sayıları için veriyi kendi içinde okuyarak, gazete ve derginin en fazla ve en az satış yapıldı̆̆ı yılları belirtmiştir. Diğer taraftan, Buse gazete ve dergi satışı arasında yıllara göre de karşılaştırma yapmış, 2016 yılında gazetenin de derginin de düşüş gösterdiğini belirtmiştir.

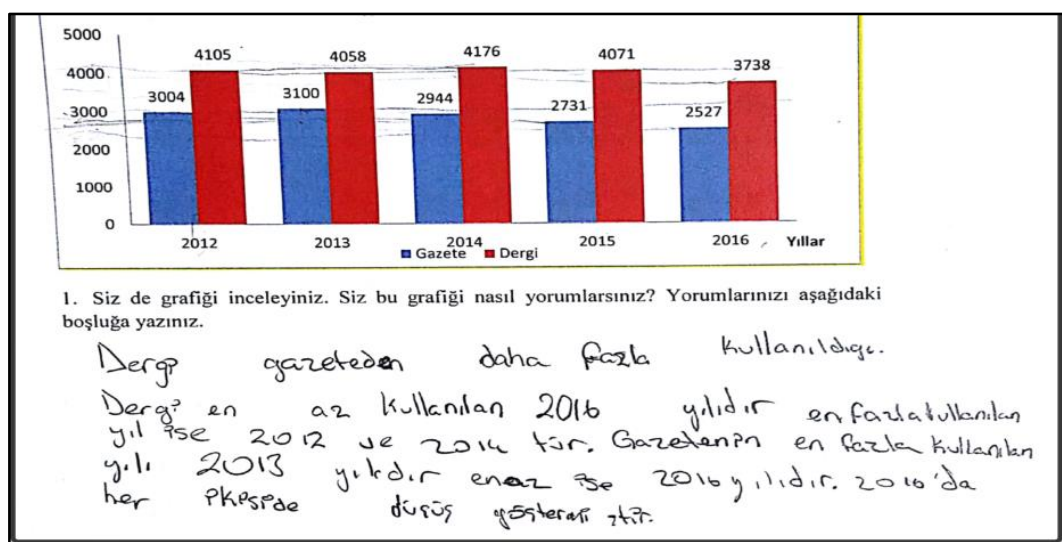

Şekil 3. Buse'nin “Gazete ve Dergi” adlı etkinliğe ait grafiği yorumlaması

Buse' nin görüşme sırasında grafiği yorumlarken kullandığ1 ifadeler, etkinlikte sunulan bağlamı tam doğru olarak yansıtmayacak şekilde grafiği yorumladığını göstermektedir. Aşağıdaki alıntıda örneklendirildiği gibi Buse, verileri gazete ve 
derginin satış sayısı olarak değil, gazete ve derginin kullanım sayısı olarak okuyarak yorumlamiştır.

A(Araştırmacı): Verilen grafiği nasıl yorumladın (yorumlar mısın)? Grafik ne anlatıyor/neyi açıklıyor? Neden?

Buse: Buraya baktığımızda kırmızılar dergiymiş, maviler de gazeteymiş. Dergiler baktığımız zaman gazeteden daha fazla kullanılmış. Derginin en az kullanıldığı yıl, 2016 yılıymış. Çünkü böyle getirdiğimizde sayılarla denk geldiğinde derginin 2016 yılında en az kullanıldığını görebiliyoruz. 2012 ve 2014'te aynıdır. En fazla 2014 ve 2012'dedir. Çünkü bunları götürdüğümüzde 4000'e denk geliyor. En fazla 4000'dir.

Buse'nin, sütun grafiklerinde doğrudan verilen verileri okuyabildiği ancak sütun grafiklerinde sütunların gösterdiği verilere ait sayısal değerleri yaklaşık olarak belirlediği görülmüştür. "Gazete ve Dergi” etkinliğinde Buse'nin ikinci, üçüncü ve dördüncü alt sorulara verdiği cevaplar incelendiğinde, Buse'nin bu soruların ilk ikisini doğru cevaplamış olduğu, son soruyu ise hatalı cevaplamış olduğu görülmüştür (bkz. Tablo 4).

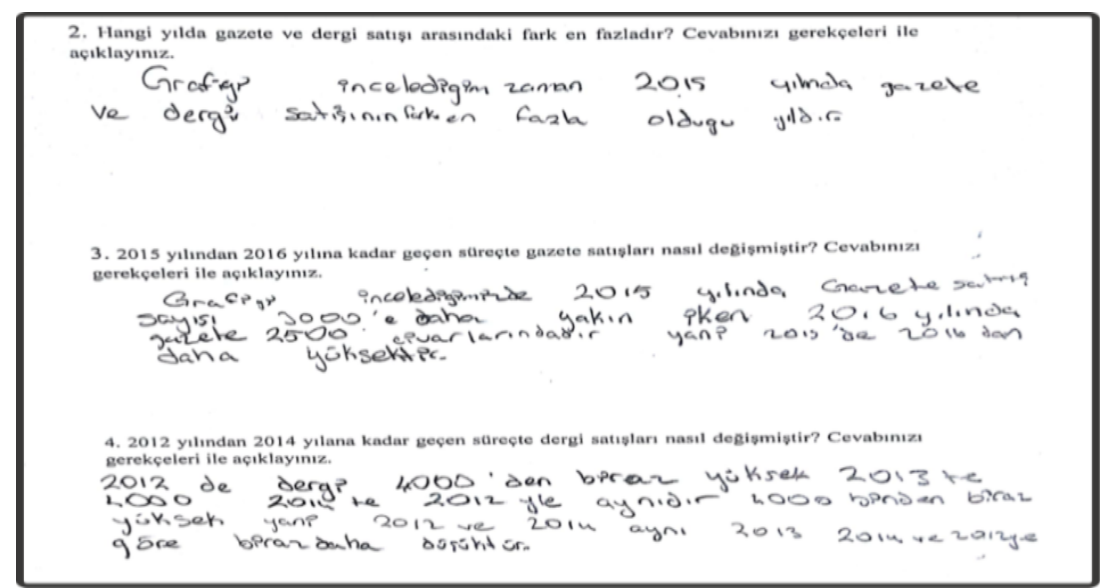

Şekil 4. Buse' nin “Gazete ve Dergi” adlı etkinliğe ait sorulara verdiği cevaplar

Şekil 4'te yer alan Buse'nin cevaplarından da görüldüğü gibi, Buse soruları cevaplarken sütunlar üzerinde yazan sayısal veriler arasındaki farka bakarak değil, sütunların uzunlukları arasındaki görsel farka bakarak yaklaşık değerleri okumuştur. Buse'nin sayısal değerleri tam olarak okumayıp, verileri yaklaşık olarak okuması dördüncü soruya hatalı cevap vermesine yol açmıştır.

Buse'nin, "Kütüphane" etkinliğinde yer alan sütun grafiğini, veriler arası okuma yaparak yorumlama düzeyi ise çok düşüktür. Şekil 5'te yer alan Buse'nin açıklamalarından görüldüğü gibi, Buse sadece en fazla ve en az ifadelerine dayalı olarak üç veri arasında bir karşılaştırma yapmıştır. Aynı zamanda Buse verilen verilerden, kütüphaneden yararlanan kişi sayısına ait verilere dayanarak, "en fazla kütüphaneden yararlanılıyormuş şeklinde" kişiye özgü bir yorumlama yapmıştır. 


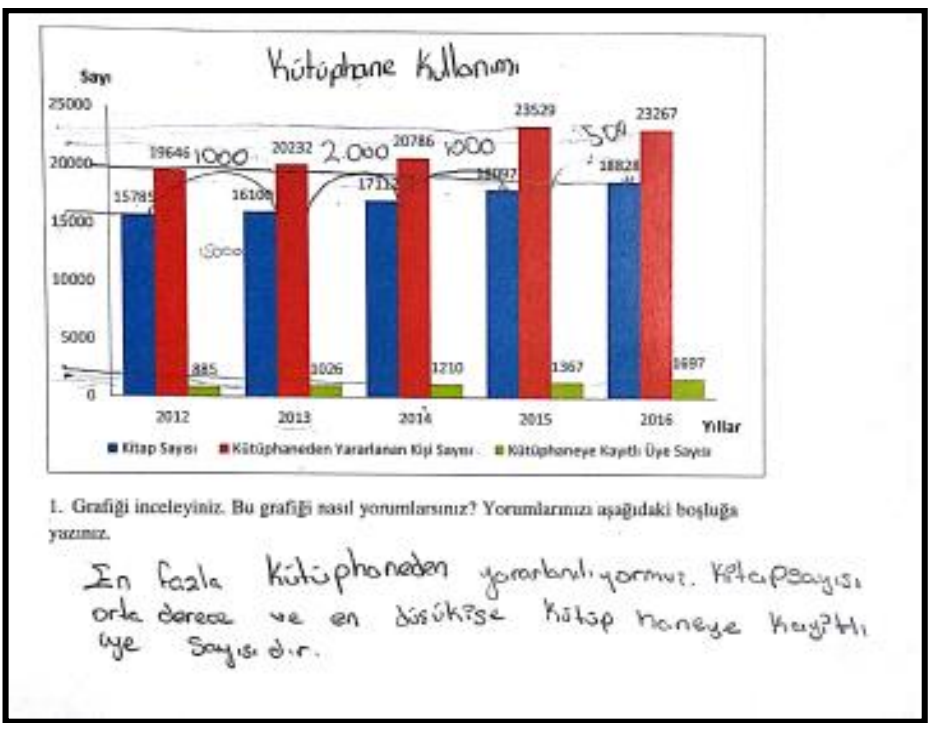

Şekil 5. Buse' nin “Kütüphane” adlı etkinliğe ait grafiği yorumlaması

Diğer taraftan Buse, "Kütüphane” etkinliğine ait diğer alt soruları cevaplarken de sütunlar üzerinde sunulmuş sayısal verileri göz ardı ederek, kendisi yaklaşık değerleri belirleyerek soruları cevaplamıştır. Buse'nin bu yaklaşımı sorulardan iki tanesini yanlış cevaplamasına sebep olmuştur (bkz. Tablo 4). Buse'nin beşinci soruya verdiği “kitap sayısindaki değişim en az 2015'ten 2016'ya, en fazla 2013'ten 2014'e artmıştır" şeklindeki yanlış cevabı Şekil 6'da gösterilmektedir. Grafikte verilen verilere göre kitap sayısı 2012-2013 yılları arasında en az değişmiştir.

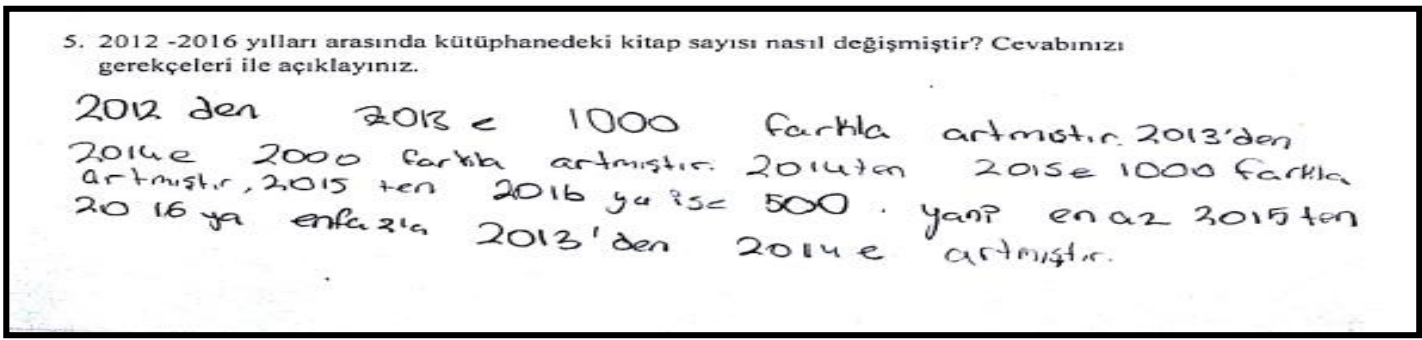

Şekil 6. Buse'nin “Kütüphane” adlı etkinlikte alt sorulardan bir tanesine vermiş olduğu hatalı cevap

Deniz'in grafik okuma ve yorumlama süreci. Tablo 3 'te sunulduğu gibi, Deniz üç etkinlikte çok düşük düzey veriler arası okuma yaparak grafikleri yorumlarken, iki etkinlikte ise düşük düzeyde veriler arası okuma yaparak grafikleri yorumlamıştır. Genel itibariyle Deniz'in veriler arası okuma yaparak grafik yorumlama düzeyi çok düşük düzey ile düşük düzey arasında değişmiştir.

Deniz, “Enerji Kaynakları” adlı etkinlikte sunulan daire grafiğini düşük düzey veriler arası okuma yaparak yorumlamıştır. Şekil 7'de görüldüğü gibi, Deniz etkinlik kâğıdında yüzdeleri okumadan, herhangi bir matematiksel ifade kullanmadan daha az, daha çok şeklinde genel bir yorumlama yapmıştır. Deniz görüşmeler sırasında ise aşağıdaki alıntıda sunulduğu gibi, etkinlik kâğıdında yazdıklarından farklı olarak sayısal değerlere yer vermiştir ancak yüzde ifadesini belirtmeden yalnızca sayı olarak belirtmiştir. Bu sebeple Deniz'in sunulan grafiği veriler arası okuyarak yorumlaması düşük düzeydedir. 


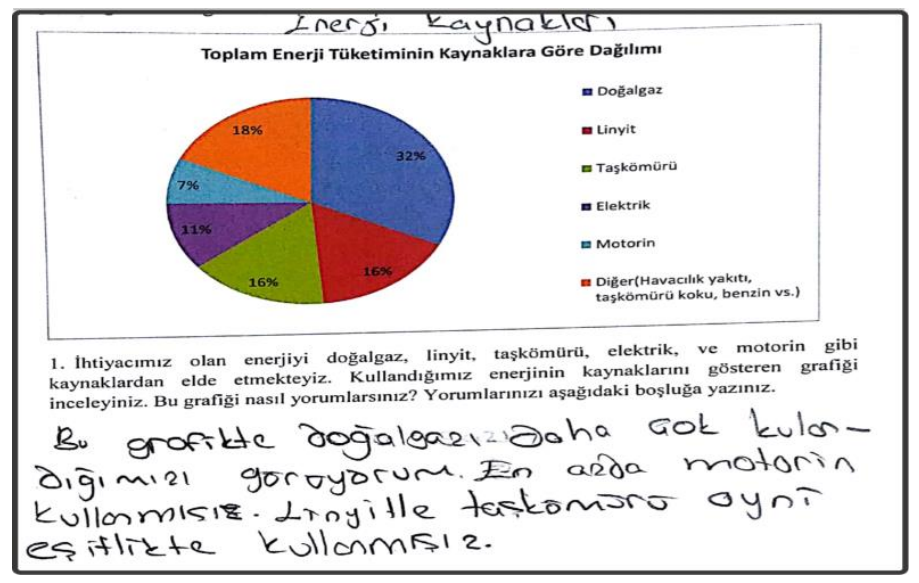

Şekil 7. Deniz' in "Enerji Kaynakları" adlı etkinliğe ait grafiği yorumlaması

A: Verilen grafiği nasıl yorumladın (yorumlar mısın)? Grafik ne anlatıyor/neyi açıklıyor? Neden?

Deniz: 360'lık bir daire çizmişler. Sırasıyla hepsini yazmışlar. Doğalgaz daha çok olduğu için daha büyük çizmişler. Sonra linyitin 16 olduğu için ondan düşük yapmışlar. Sonra taşkömürü eşitmiş linyitle. Eşit bir boşluk vermişler. Elektrik 11 kadar bir şeymiş. 16'la 32'den daha az vermişler. Motorin 7'ymiş. En az olduğu için en az bölgeyi de ona vermişler. Diğer yakıtlar da 18'miş. 16'dan büyük 32'den de biraz küçük.

Aynı zamanda, yukarıda sunulan alıntıda görüldüğü gibi, Deniz daireyi \%100 olan bir bütün olarak değil, 360'lık bir bütün olarak ifade ederek hatalı bir yorumlama yapmiştır.

Deniz'in "Enerji Kaynakları" etkinliğine ait ikinci ve üçüncü alt soruları doğru cevaplamış olduğu ancak sayısal değer belirtmeden grafiğin görseline dayalı olarak cevap vermiş olduğu görülmektedir (bkz. Tablo 4). Şekil 8'de örnek olarak sunulduğu gibi, Deniz etkinlik kâğıdında üçüncü soruya, daire grafiğinde yer alan yüzde değerini belirtmeden cevap vermiştir.

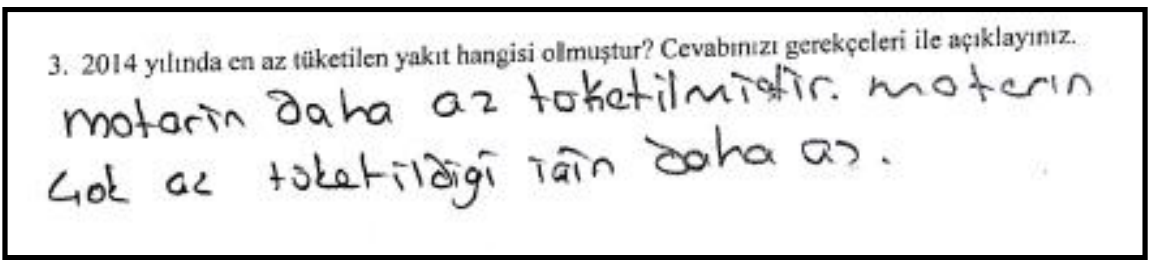

Şekil 8. Deniz'in “Enerji Kaynakları” adlı etkinliğe ait üçüncü soruya verdiği cevap

Deniz, “Kütüphane” etkinliğinde sunulan sütun grafiğini ise çok düşük düzey veriler arası okuma yaparak yorumlamıştır. Şekil 9’da sunulduğu gibi, Deniz sayısal değerler belirtmeden görsele dayalı olarak grafiği yorumlamış, sadece 2012 yılında üç verinin birbirine göre durumunu karşılaştırmıştır. Diğer yıllar için ise sütun boyutlarına ait görsele dayalı olarak tüm yıllarda 2012 yılı için ifade ettiği gibi devam ettiğini belirtmiştir. Fakat yıllara göre bir karşılaştırma yapmamıştır. Deniz grafiği yorumlarken genel trendi yorumlamadığı, sayısal verileri kullanmadan görsele dayalı, sadece en fazla ve en düşük ifadelerini kullanarak yorumladığı için veriler arası okuma düzeyi çok düşüktür. 


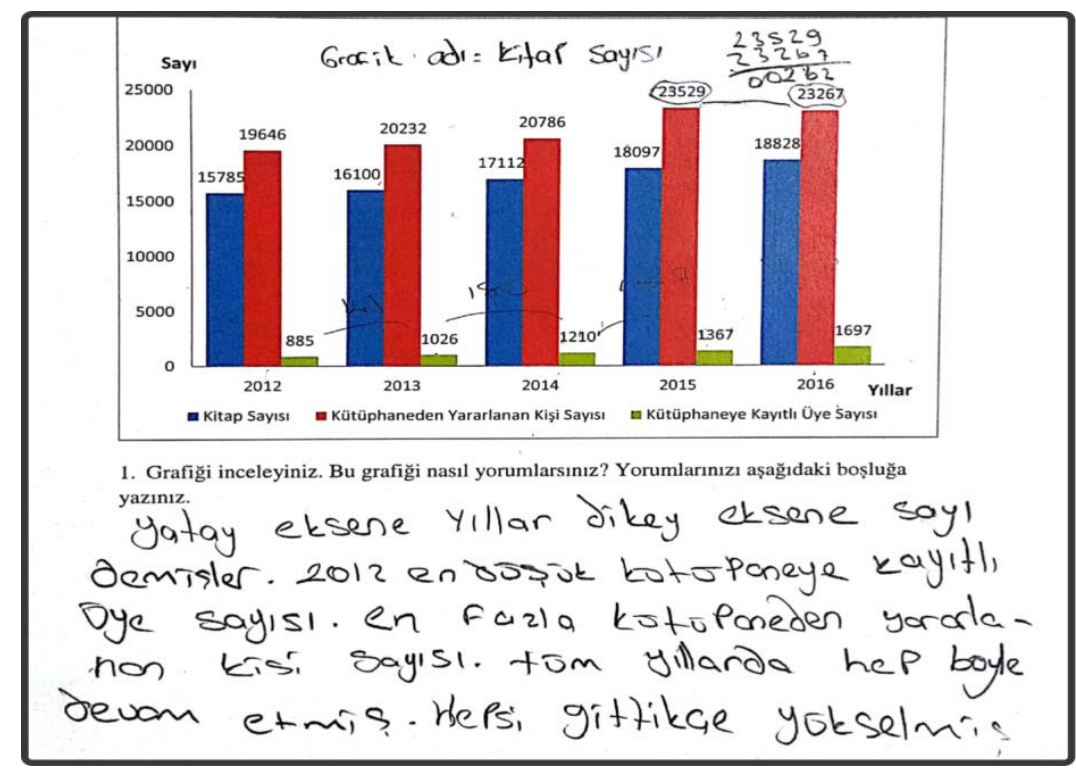

Şekil 9. Deniz'in "Kütüphane" adlı etkinliğe ait grafiği yorumlaması

Aşağıda sunulan alıntıda görüldüğü gibi Deniz, görüşmeler sırasında "Kütüphane" etkinliğine ait grafiği yorumlarken, grafiğin nasıl çizildiğini anlatmış ve grafiği genel olarak sayısal değerler belirtmeden yorumlamıştır.

A: Verilen grafiği nasıl yorumladın (yorumlar mısın)? Grafik ne anlatıyor/neyi açıklıyor? Neden?

Deniz: Yatay eksene yıllar demiş. Çünkü 2012, 2013 diye sırasıyla yazmışlar. Dikey eksene de sayısını yazmışlar, ne kadar olduğunu. Bu grafik, kitap sayısı, kütüphaneden yararlanan kişi sayısı ve kütüphaneye kayıtlı kişi sayısını anlatıyor.

Deniz, "Kütüphane" etkinliğine ait diğer alt soruları cevaplarken, sayısal verileri doğru okumuş, doğru sayısal hesaplamalar yaparak sorulan soruların dördünü de doğru cevaplamıştır (bkz. Tablo 4).

Ömer'in grafik okuma ve yorumlama süreci. Tablo 3 'te sunulduğu gibi, Ömer bir etkinlikte sunulan grafikte orta düzeyde veriler arası okuma yaparak grafiği yorumlarken, dört etkinlikte sunulan grafiklerde ise çok düşük düzeyde veriler arası okuma yaparak grafikleri yorumlamıştır. Aynı zamanda, Ömer'in "Hayvansal Üretim" ve "İhraç Miktarı ve İhraç Ürünleri" adlı etkinliklere ait grafiklerde kişiye özgü yorum da yapmış olduğu görülmüştür. Genel itibariyle Ömer'in veriler arası okuma yaparak grafik yorumlama düzeyi çok düşük düzey ile orta düzey arasında değişmiştir.

Ömer "Hayvansal Üretim" etkinliğine ait sunulan grafikte orta düzeyde veriler arası okuma yaparak grafiği yorumlamıştır. "Hayvansal Üretim" etkinliğine ait, Şekil 10'da yer alan Ömer' in açıllamalarından görüldüğü gibi, Ömer hem her bir hayvan miktarının kendi içinde yıllara göre değişimini yorumlamış, hem de hayvanların kendi arasındaki artışın değişimini karşılaştırmıştır. Ömer, grafiği yorumlarken sığır, koyun ve keçi sayılarına ait verileri, kendi içinde yıllara göre okumuş ve sığır, keçi ve koyun sayıları arasındaki sayısal verileri karşılaştırarak verileri okumuştur. En fazla ve en az değerleri belirleyebilmiştir. Fakat Ömer grafiği 
yorumlarken sayısal verilerden faydalansa da genel trendi yorumlamamıştır. Diğer taraftan, aşağıdaki alıntıda sunulduğu gibi, Ömer görüşmeler sırasında grafiği, etkinlik kâğıdında yazdıklarıyla benzer şekilde sayısal değerler kullanarak doğru yorumlamıştır. Ömer sütunları karşılık gelen sayısal değerleri ile eşleştirerek belirlemiştir. Keçi üretimi için ise kişisel yorum katarak hiç üretilmemiş diyebileceğini belirtmiştir.

A: Verilen grafiği nasıl yorumladın (yorumlar mısın)? Grafik ne anlatıyor/neyi açıklıyor? Neden?

Ömer: Sayıların aralarına çizgiler çizdim. Çünkü tam 15 olmadiğı için ne kadar olduğunu bulmak için. Sığır (2016) 14 çıktı. Yani 14 milyon üretilmiş. 2017 yılında 18 milyon üretilmiş. Yani bir yıl arasında artış olmuş. Koyunda müthiş bir artış var. Sığıra göre fena bir yetiştiricilik var. 2016 yılında 30, 2017 yılında 35 üretilmiş. Keçi sayısına zaten hiç üretilmemiş gibi de diyebiliriz. Bu grafik sığır, koyun ve keçinin üretim miktarların anlatıyor.

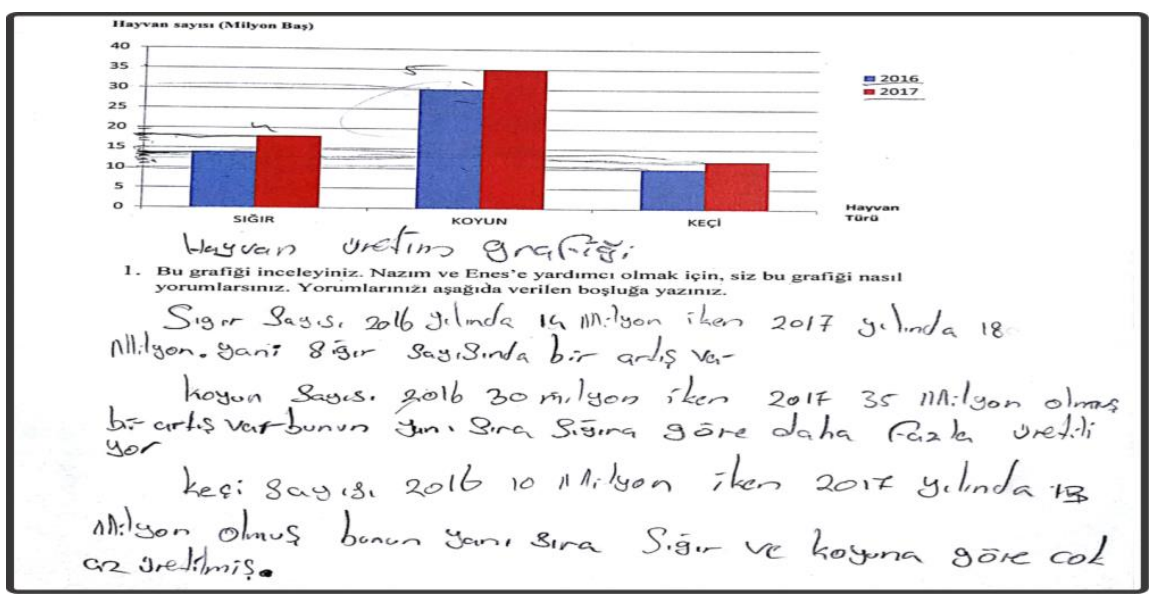

Şekil 10. Ömer'in "Hayvansal Üretim" adlı etkinliğe ait grafiği yorumlaması

Diğer taraftan Ömer'in, grafikte doğrudan verilen verileri okumakta zorluk çekmeden, verileri sayısal değerlere dayalı olarak okuyabildiği görülmüştür. Ömer, "Hayvansal Üretim" etkinliğine ait iki alt soruyu da doğru cevaplamıştır (bkz. Tablo 4). Şekil 11'de sunulduğu gibi, Ömer grafik üzerindeki sayısal değerleri doğru okuyarak sorulara tam doğru açıklayıcı cevaplar vermiştir.

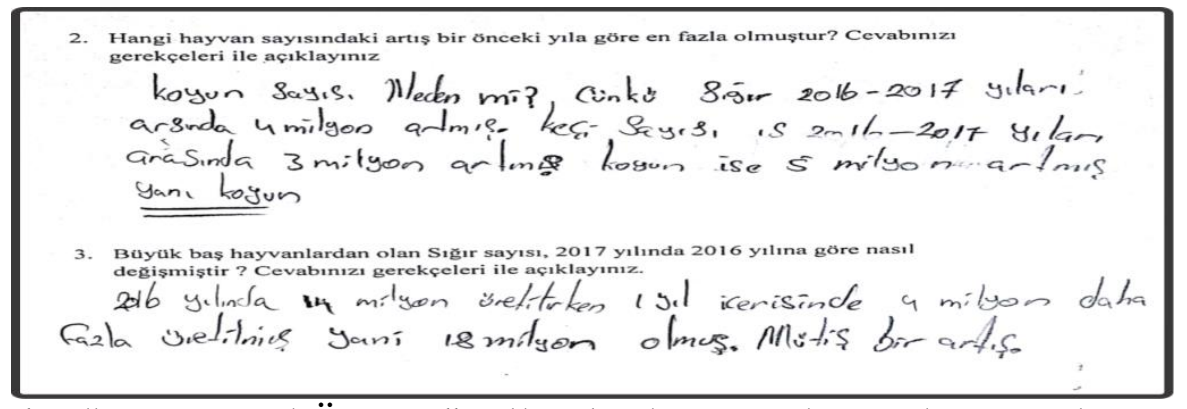

Şekil 11. Ömer' in "Hayvansal Üretim" adlı etkinliğe ait alt sorulara verdiği cevaplar

Ömer "İhraç Miktarı ve İhraç Ürünleri" etkinliğinde sunulan ilk grafikte ise çok düşük düzeyde veriler arası okuyarak ve verileri kişiye özgü okuyarak grafiği yorumlamıştır. Şekil 12'de sunulduğu gibi, Ömer veriyi okurken sayısal değerler 
belirtmeden en az, en çok ifadeleriyle yorumlamıştır. Ömer, yorumunda 2008 y1lı diğer yıllara göre daha kârlı olmuş şeklinde bir ifade kullanarak, kişiye özgü bir yorumlama da yapmıştır. Ömer, görüşmeler esnasında da etkinlik kâğıdında yazılandan daha fazla yorum yapamamıştır. Hatta Ömer, görüşmeler sırasında grafiği yorumlarken yanlış okumuştur. “İhraç Miktarı ve İhraç Ürünleri” grafiği için maliyet fiyatlarının gösterildiğini söylemiştir. Etkinliğe ait ikinci grafiği yorumlarken ise sayısal değerleri kullanmadan görsele bağlı olarak okumuş ve kişiye özgü ifadelere yer vermiştir.

A: Verilen grafiği nasıl yorumladın (yorumlar mısın)? Grafik ne anlatıyor/neyi açıklıyor? Neden?

Ömer: Önce baktım. 2000 yılıyla 2008 yılları arasında maliyet fiyatları gösterilmiş. Baktım bir artış var. Karlı bir iş. İkinci grafikte de satılan şeyler var. En fazla pantolon satılmış. Gömlek en az satılmış gibi. Hiç satılmamış hatta. Çünkü dilimlerine bakarak söyledim.

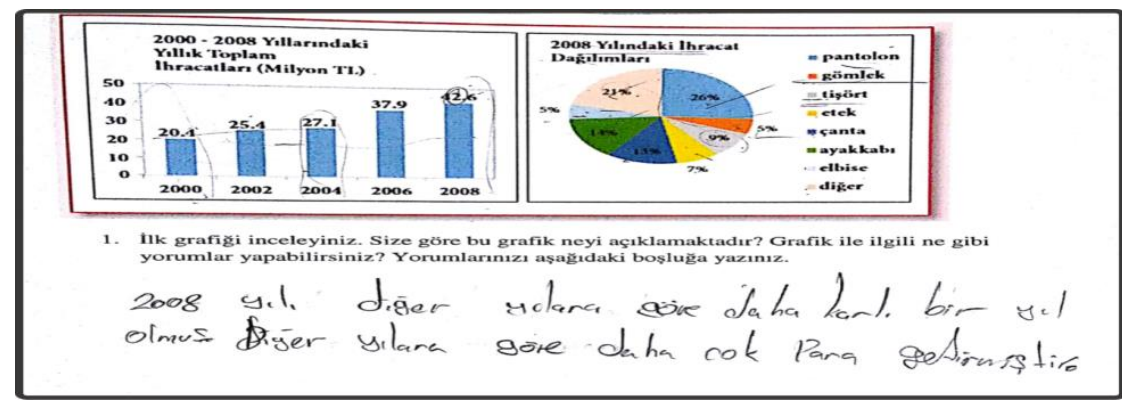

Şekil 12. Ömer'in “İhraç Miktarı ve İhraç Ürünleri” adlı etkinliğe ait grafiği yorumlamas1

Diğer taraftan, Ömer'in ikinci ve üçüncü soruları grafikteki sayısal değerleri okuyarak doğru cevaplamış olduğu görülmüştür (bkz. Tablo 4). Fakat Ömer, iki grafiğin birbiri ile ilişkili olduğu dördüncü soruyu ise herhangi bir sayısal işlem yapmadan grafiğin yalnızca yüzdelik değerlerine bakarak ve kişisel yorum yaparak yanlış cevaplamıştır. Elbise ve gömleğin yüzdelerinin eşit olduğunu doğru okumuş ancak yaklaşık değer belirleyip 1,5 milyondan küçük olacă̆1 yorumunu yaparak küçük bir değere sahip olacaklarını belirtmiştir.

Sevgi'nin grafik okuma ve yorumlama süreci. Tablo 3'te sunulduğu gibi, Sevgi'nin bir etkinlikte sunulan grafikte çok düşük düzeyde, bir etkinlikte sunulan grafikte düşüu düzeyde, bir etkinlikte sunulan grafikte ise orta düzeyde veriler arası okuma yaparak grafikleri yorumladiğı görülmüştür. Diğer taraftan iki etkinlikte sunulan grafikte veriler arası okuma yapamadan grafikleri yorumladığı görülmüştür. Genel itibariyle Sevgi'nin veriler arası okuma yaparak grafik yorumlama düzeyi çok düşük düzey ile orta düzey arasında değişmiştir.

Şekil 13'te, "Kütüphane" etkinliğine ait grafikte Sevgi'nin veriler arası okuma yapmadığı örneklendirilmektedir. Sevgi ne kitap sayısının ve kütüphaneden yararlanan kişi sayısının ne de kütüphaneye kayıtlı üye sayısının yıllara göre değişimini yorumlamıştır. Sevgi grafikteki verileri kendi içinde ve arasında yorumlamamış, herhangi bir sayısal değeri okumamış ve genel olarak bir açıklama yapmiştır. 


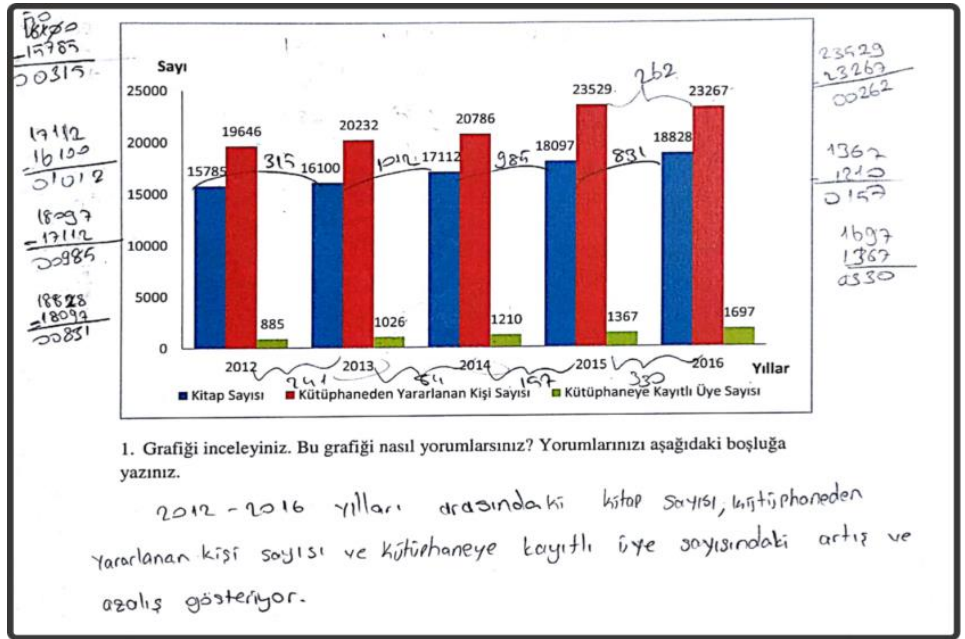

Şekil 13. Sevgi' nin “Kütüphane" adlı etkinliğe ait grafiği yorumlaması

Aşağıdaki alıntıda sunulduğu gibi Sevgi'nin "Kütüphane" etkinliğini görüşmeler sırasındaki yorumlaması da etkinlik kâğıdıyla benzer şekildedir ve görüşmeler esnasında da veriler arası okuma yaparak grafiği yorumlamamıştır. Sevgi grafiği yorumlamak yerine grafikte hangi verilerin yer aldığını belirtmiştir.

A: Verilen grafiği nasıl yorumladın (yorumlar mısın)? Grafik ne anlatıyor/neyi açıklıyor? Neden?

Sevgi: 2012-2016 yılları arasında, kitap sayısı, kütüphaneye kayıtlı üye sayısı, kütüphaneden yararlanan kişi sayısını göstermiş. Kitap sayısını maviyle, kütüphaneden yararlanan kişi sayısını kırmızıyla, kütüphaneye kayıtlı üye sayısını yeşille göstermiş.

Diğer taraftan, Sevgi “Kütüphane" etkinliğine ait diğer tüm alt soruları doğru cevaplamıştır (bkz. Tablo 4).

Şekil 14'te sunulduğu gibi, Sevgi'nin "Enerji Kaynakları" etkinliğinde sunulan grafikte ise veriler arası okuyarak grafiği yorumlama düzeyi düşüktür. Sevgi grafiği, sayısal değerleri kullanmadan en az, en fazla ve eş enerji ifadelerini kullanarak yorumlamıştır. Ayrıca bağlamı tam anlamamış ve yanlış okumuştur. Diğer bir deyişle, enerji tüketiminin kaynaklara göre dağılımını, kaynaklar (doğalgaz, linyit, taşkömürü, elektrik, motorin, diğer) için kullanılan enerji olarak okumuştur. Sevgi görüşmeler sırasında da etkinlik kâğıdında yazdıklarına benzer şekilde sayısal değerler kullanmadan görsele dayalı olarak yorumlamıştır. Sevgi'nin yorumu aşağıdaki alıntıda sunulmuştur.

A: Verilen grafiği nasıl yorumladın (yorumlar mısın)? Grafik ne anlatıyor/neyi açıklıyor? Neden?

Sevgi: En fazla doğalgaz için kullanılmış. Taşkömürü ve linyit için eşit miktarda kullanmış. En az enerji motorinde. Bu grafik enerji kaynaklarının kullanım miktarın gösteriyor. 


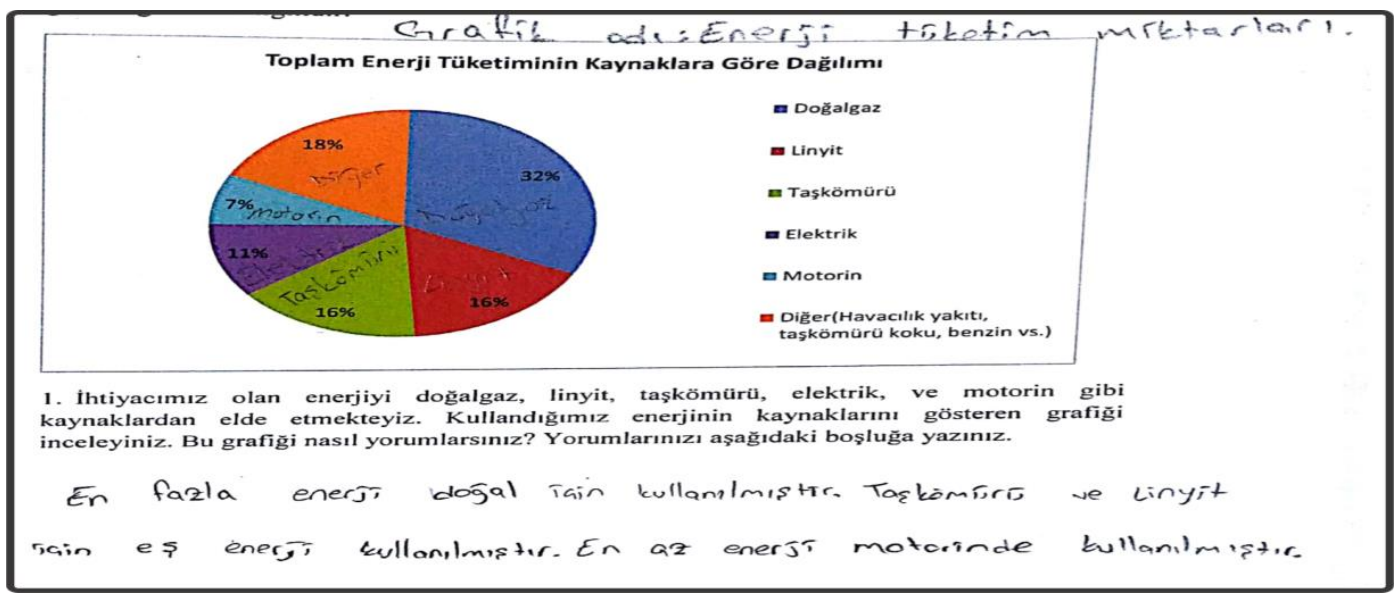

Şekil 14. Sevgi'nin “Enerji Kaynakları” adlı etkinliğe ait grafiği yorumlaması

Diğer taraftan, Sevgi "Enerji Kaynakları" etkinliğine ait iki alt soruyu da doğru cevaplamıştır. Fakat Şekil $15^{\prime}$ te sunulduğu gibi, Sevgi, grafikte tüketilen her bir yakıt miktarı için belirtilmiş yüzde değerlerini okumadan, yalnızca görsele dayalı olarak, yani daire dilimlerinin boyutlarına bakarak soruları cevaplamıştır.

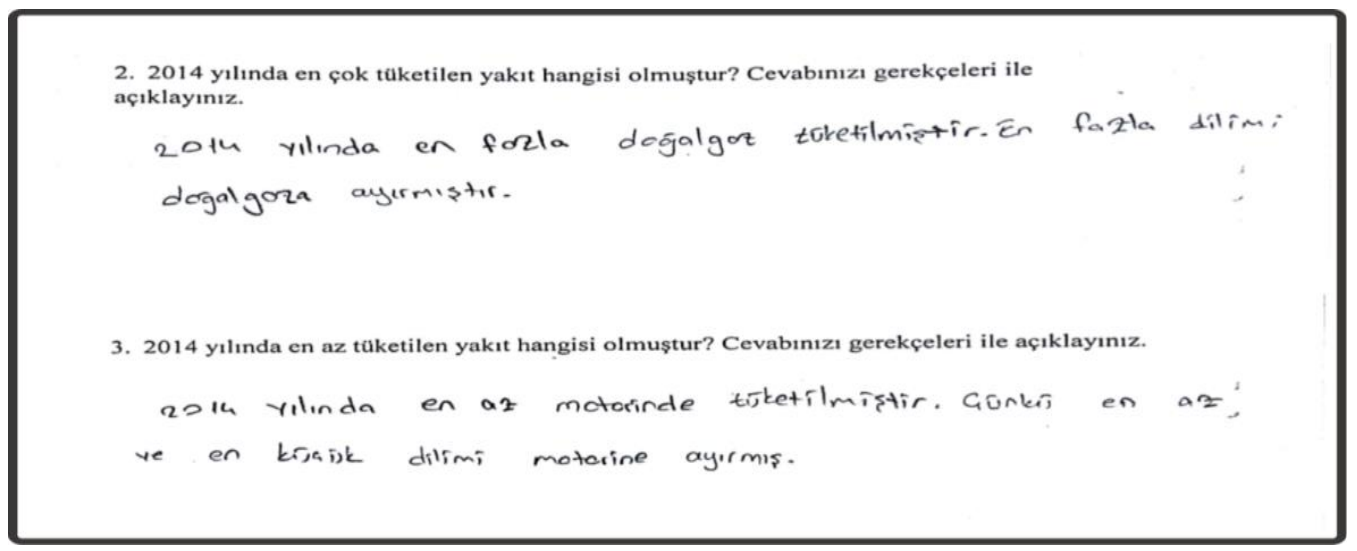

Şekil 15. Sevgi'nin “Enerji Kaynakları” etkinliğine ait alt sorulara verdiği cevaplar

İlkay'ın grafik okuma ve yorumlama süreci. Tablo 3'te sunulduğu gibi, İlkay bir etkinlikte sunulan grafiği orta düzeyde veriler arası okuma yaparak, üç etkinlikte sunulan grafikleri düşük düzeyde veriler arası okuma yaparak, bir etkinlikte sunulan grafiği ise çok düşük düzeyde veriler arası okuma yaparak yorumlamıştır. Genel itibariyle İlkay'ın veriler arası okuma yaparak grafik yorumlama düzeyi çok düşük düzey ile orta düzey arasında değişmiştir.

İlkay "Hayvansal Üretim" etkinliğinde orta düzeyde veriler arası okuma yaparak grafiği yorumlamıştır. Şekil 16' da sunulduğu gibi İlkay grafiği yorumlarken sayısal değerleri kullanmış, sı̆̆ır, koyun ve keçi sayılarını kendi içinde yıllara göre ve sığır, keçi ve koyun sayılarını kendi arasında karşılaştırma yaparak grafiği yorumlamıştır. Fakat İlkay grafikle sunulan verilerde genel trendi yorumlamamıştır. Bu sebeple veriler arası okuma düzeyi orta düzeydedir. 


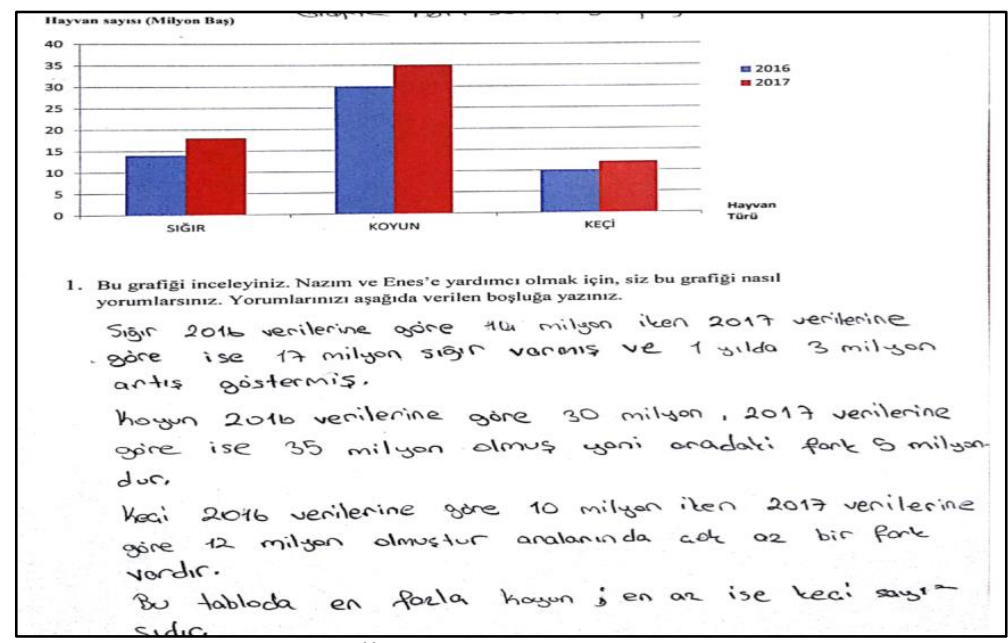

Şekil 16. İlkay'ın "Hayvansal Üretim” adlı etkinliğe ait grafiği yorumlaması

Diğer taraftan, İlkay "Hayvansal Üretim" etkinliğine ait iki alt soruyu da sayısal değerleri okuyarak doğru cevaplamıştır (bkz. Tablo 4).

İlkay "Enerji Kaynakları" etkinliğinde düşük düzeyde veriler arası okuma yaparak grafiği yorumlamıştır. İlkay grafiği yorumlarken, Şekil 17'de sunulduğu gibi sayısal değerleri kullanmıştır ancak yalnızca en az ve en fazla yüzde değerlerini belirterek enerji ihtiyacının karşılandığı kaynaklar arasında karşılaştırma yapmış, diğer kaynaklar arasında bir karşılaştırma yapmamıştır. Bu sebeple İlkay'ın veriler arası okuma düzeyi düşüktür.

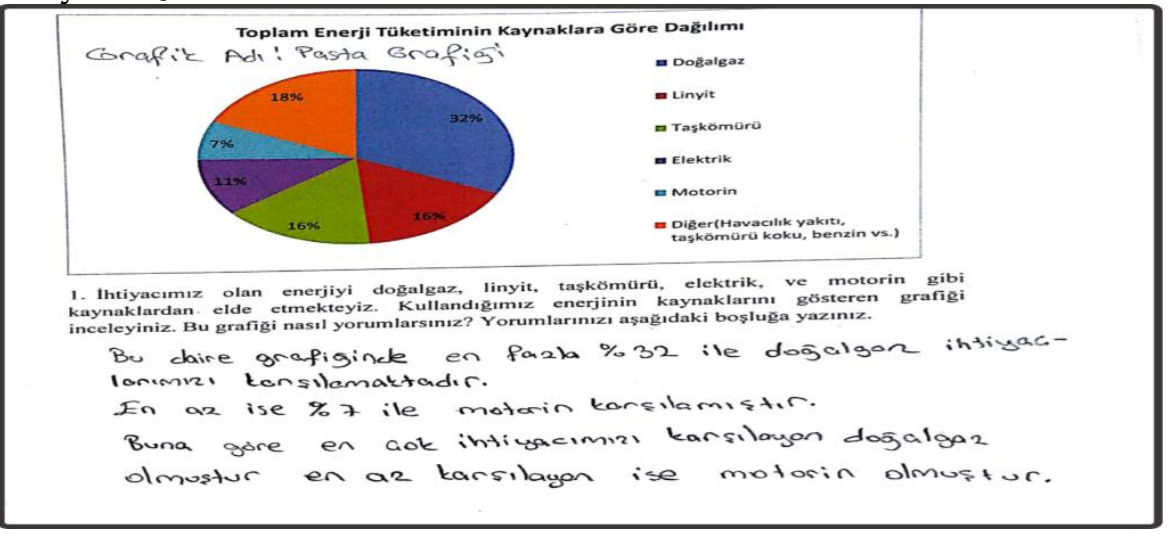

Şekil 17. İlkay'ın “Enerji Kaynakları” adlı etkinliğe ait grafiği yorumlaması

İlkay görüşmeler sırasında "Enerji Kaynakları" etkinliğini yorumlarken aşağıdaki alıntıda sunulduğu gibi etkinlik kâğıdıyla benzer şekilde genel bir yorumlama yapmıştır. En az ve en fazla değerlerden sayısal verileri kullanmadan bahsetmiştir.

A: Verilen grafiği nasıl yorumladın (yorumlar mısın)? Grafik ne anlatıyor/neyi açıklıyor? Neden?

Illkay: Bu grafik toplam enerji tüketimini anlatıyordu. Ben bunu yüzdelerine bakarak karar verdim. Öyle yorumladım. En fazla doğalgazdı. En az ise motorindi.

İlkay "Enerji Kaynakları" etkinliğine ait iki alt soruyu da sayısal verileri doğru okuyarak doğru cevaplamıştır (bkz. Tablo 4). 


\section{Tartışma, Sonuç ve Öneriler}

$\mathrm{Bu}$ çalışmada beş yedinci sınıf öğrencisinin sütun ve daire grafiklerini okuma ve yorumlama düzeyleri incelenmiştir. Çalışmanın bulguları, herhangi bir yönlendirme olmadan öğrencilerin grafikleri kendi yorumlamalarının istendiği yapılandırılmamış, açı uçlu olarak hazırlanan birinci alt soruda, grafikleri çok düşük düzeyden orta düzeye kadar değişen üç farklı düzeyde veriler arası okuma yaparak yorumladıklarını ortaya koymuştur. Öğrencilerin grafik yorumlama düzeyleri arasında belli bir düzen olmayıp, yorumlama düzeyleri hem öğrencilere hem de etkinliklere göre değişiklik göstermiştir. Başka bir deyişle, bir öğrenci bir etkinlikte sunulan grafiği çok düşük düzeyde veriler arası okuma yaparak yorumlarken, aynı öğrenci başka bir etkinlikte sunulan grafiği orta düzeyde veya çok düşük düzeyde veriler arası okuma yaparak yorumlamıştır. Aynı zamanda, bir öğrenci bir etkinlikte sunulan grafiği düşük düzeyde veriler arası okuma yaparak yorumlarken, başka bir öğrenci aynı grafiği orta düzeyde veriler arası okuma yaparak yorumlamıştır. Genel olarak, beş öğrencinin de grafiklerde sunulan tüm verileri incelemeden, değerlendirmeden ve sadece bazı verilere odaklanarak grafikleri yorumladıkları, genel trendi yorumlama eğilimi içinde olmadıkları ve yüksek düzeyde veriler arası okuma yaparak grafikleri yorumlayamadıkları görülmüştür. Bu bulgu öğrencilerin, yorumlamaya dayalı açık uçlu sorularda grafiğin ne anlattığını yorumlayarak ve kritik ederek bakmadıklarını, daha çok belli verilere odaklanarak soruya bir cevap verme eğilimi içinde olduklarına işaret etmektedir. Bu çalışmaya katılan ortaokul öğrencilerinin sütun ve daire grafiğini yorumlama düzeylerinin düşük olması ile ilgili bulgular, Yılmaz ve Ay'ın (2016) çalışmasına katılan 8. sınıf öğrencilerinin histogramı yorumlama eksikliklerinin olduğu bulgusu ile benzerlik göstermektedir. Diğer taraftan ise çalışmanın bulguları, öğrencilerin verileri grafikten doğrudan okuyarak ve karşılaştırarak cevap verecekleri yapılandırılmış soruların birçoğunu doğru cevapladıklarını, sadece birkaç soruda yanlış cevap verdiklerini ortaya koymuştur. Öğrencilerin grafikleri yorumlamalarının kendilerine bırakıldı̆̆ durumdan farklı olarak, yapılandırılmış soruların sütun grafiklerinde yer alan "20122016 yılları arasında kütüphanedeki kitap sayısı nasıl değişmiştir? Cevabınızı gerekçeleri ile açıklayınız" şeklindeki genel trendi yorumlama sorularında, öğrenciler doğru ve açıklayıcı cevaplar vermişlerdir. Yani öğrenciler birinci alt soruda kendileri grafikleri yorumlarken genel trendi yorumlama eğiliminde olmasalar da, genel trendin doğrudan sorulduğu sorulara başarılı bir şekilde cevap vermişlerdir. Bu bulgu öğrencilerin grafiğin genel eğiliminin doğrudan sorulduğu sorularda verileri inceleyerek doğru bir şekilde yorumlayabildiklerini göstermiştir. Bu çalışmaya katılan ortaokul öğrencilerinin sütun ve daire grafiği verilerini okuma sürecinde başarılı olmaları ile ilgili bulgular, Sezgin-Memnun'un (2013) çalışmasına katılan 7. sınıf öğrencilerinin büyük çoğunluğunun çizgi grafiğini okuma becerisine sahip oldukları bulgusu ile benzerlik göstermektedir. Benzer şekilde, bu bulgular, lise düzeyinde öğrenim gören öğrencilerle yapılan bazı çalışmaların (Aoyama, 2007; Hafiyusholeh vd., 2018) bulguları ile benzerlik göstermektedir. Bu çalışmaların (Aoyama, 2007; Hafiyusholeh vd., 2018) bulguları da ortak olarak, grafiklerde sunulan verileri lise düzeyindeki öğrencilerin okuyabildiklerini ortaya koyarken, öğrencilerin genellikle grafikteki veriler arası ilişkileri okumada ve verilerin ötesinde okumada yani verilere dayalı tahmin yapmada veya çıkarım yapmada zorluklar yaşadıklarını ortaya koymuştur. 
Bu çalışmaya katılan öğrencilerin verileri okumada, veriler arası okumaya göre daha başarılı olmalarının sebeplerinden bir tanesi, bu çalışmada kullanılan yapılandırılmış şekilde hazırlanan soruların, ders kitaplarında veya öğretmenler tarafından derslerde kullanılan yardımcı kaynaklarda yer alan soru örnekleri ile benzer olması durumu ile açıklanabilir. Yanık, Özdemir ve Eryılmaz-Çevirgen (2017), ortaokul (5, 6, 7 ve 8. sınıf) matematik ders kitaplarında veri işlemeye yönelik etkinliklerin nasıl ele alındığını inceledikleri çalışmasında, ders kitaplarının genellikle veri işleme öğrenme alanının veri analizi bileşeni ile ilgili kazanımlara ağırlık verdiğini, kitaplarda yer alan görevlerin daha çok matematiksel işlem yaparak tespitte bulunmayı gerektiren görevler olduğunu ve çok sınırlı düzeyde yorumlama yapma ve sonuç çıkarmayı gerektiren görevlerin yer aldığını ortaya koymuşlardır.

$\mathrm{Bu}$ çalışmada alan yazındaki öğrencilerin grafik okuma ve yorumlama süreçlerini ve becerilerini çoktan seçmeli grafik testleri ile inceleyen uluslararası çalışmalardan (Aoyama, 2007; Curcio, 1987) farklı olarak, öğrencilerin günlük hayatlarında istatistiksel grafiklerle karşılaştıklarında, grafikleri ne düzeye kadar okuyup, yorumlayabildiklerini inceleyen açık uçlu sorularla grafik okuma ve yorumlama düzeyleri incelenmiştir. Diğer taraftan bu çalışmada öğrencilerin çizgi grafiğini ve histogramı okuma ve yorumlama düzeylerini inceleyen ulusal çalışmalardan (Sezgin-Memnun, 2013; Yayla ve Özsevgeç, 2015; Yılmaz ve Ay, 2016) farklı olarak öğrencilerin sütun ve daire grafiği okuma ve yorumlama düzeyleri incelenmiştir. Çalışmanın sonuçları çalışmaya katılan öğrencilerin grafik verilerini basit düzeyde okuyup yorumlayabildiklerini, fakat öğrencilerin eleştirel, yorumlayıc1 ve bütünsel bir bakış açısıyla verilerin ne anlattığına odaklanmak yerine, sadece verinin belli bir kısmına odaklandıklarını göstermiştir. Bright ve Friel (2012) matematiğin çoğunlukla prosedürlere dayalı öğretilirken, istatistiğin çok az bir kısminın prosedüre uygun olduğunu belirtmiştir. Bu sebeple, derslerin belli prosedürler yerine, kritik sorgulama çerçevesinde düzenlenmesi gerektiğini ifade etmiştir.

$\mathrm{Bu}$ çalışmaya katılan öğrenciler kendi okullarında ve sınıflarında genel akademik ve matematik dersi başarı düzeyleri yüksek olan öğrencilerdir. Bununla birlikte, bu çalışmada elde edilen bulgular, öğrencilerin akademik başarı düzeyleri yüksek olmasına karşın istatistiksel okuryazarlık kapsamında grafik okuma ve yorumlama becerilerinin yüksek düzeyde olmadığına işaret etmiştir. Bu çalışma ilişkisel bir araştırma olmadığından, gelecek çalışmalarda matematik başarı düzeyi ve istatistiksel grafikleri yorumlamalarıyla ilgili ilişkisel bir çalışma yapılabilir. Aynı zamanda, yapılacak olan yeni çalışmalarda farklı sınıf seviyelerinden ve farklı başarı düzeylerinden öğrencilerin katılımıyla, katılımcı sayısı arttırılarak, öğrencilerin farklı tip grafikleri yorumlama sürecini inceleyen nitel, nicel veya karma araştırmalar yapılabilir. $\mathrm{Bu}$ çalışma matematik öğretmenlerine veri işleme öğrenme alanının öğretiminde, öğrencilerin istatistiksel okuryazarlı̆̆ını geliştirmelerine yönelik, istatistiksel bilgiyi yorumlayıcı ve eleştirel yönde ele aldıkları etkinliklere yer vermelerini önermektedir. Buna ek olarak, öğretmenlere sadece ders kitaplarındaki bilginin doğrudan istendiği örneklere bağlı kalmayıp, bu çalışmada yer alan etkinliklere benzer olarak, gazete, dergi gibi farklı medya araçlarında tablo ve grafiklerle sunulan istatistiksel haberleri getirip öğrencilere bu bilgileri yorumlatmalarını önermektedir. 


\section{Kaynakça}

Aoyama, K. (2007). Investigating a hierarchy of students' interpretations of graphs. International Electronic Journal of Mathematics Education, 2(3), 298-318.

Aoyama, K., and Stephens, M. (2003). Graph interpretation aspects of statistical literacy: A japanese perspective. Mathematics Education Research Journal, 15(3), 207-225.

Arteaga, P., Batanero, C., Contreras, J. M., and Cañadas, G. R. (2015). Statistical graphs complexity and reading levels: A study with prospective teachers. Statistique et Enseignement, 6(1), 3-23.

Aydın, H., Özdoğan, M. A. ve Koçak, F. (2017). Ortaokul ve imam hatip ortaokulu matematik uygulamaları Ankara: Milli Eğitim Bakanlığı Yayınları.

Ben-Zvi, D., and Garfield, J. (Editörler). (2004). The challenge of developing statistical literacy, reasoning and thinking. Dordrecht: Kluwer Academic Publishers.

Bestgen, B. J. (1980). Making and interpreting graphs and tables: Results and implications from national assessment. The Arithmetic Teacher, 28(4), 26-29.

Bright, G. W., and Friel, S. N. (2012). Graphical representations: Helping students interpret data. S. P. Lajoie (Editör), Reflections on statistics: learning, teaching, and assessment in grades K-12 (s. 63-88). Mahwah, NJ: Erlbaum.

Curcio, F. R. (1981). The effect of prior knowledge, reading and mathematics achivement, and sex on comprehending mathematical relationships expresssed in graphs. Final report. Brooklyn, NY: St. Francis College.

Curcio, F. R. (1987). Comprehension of mathematical relationships expressed in graphs. Journal for Research in Mathematics Education, 18(5), 382-393.

Erbilgin, E., Arıkan, S. ve Yabanlı, H. (2015). Çizgi grafiğini yorumlama ve oluşturma becerilerinin ölçülmesi. Ahi Evran Üniversitesi Kırşehir Eğitim Fakültesi Dergisi (KEFAD), 16(2), 43-61.

Ev-Çimen, E. ve Yıldız, Ş. (2018). Altıncı sınıf öğrencilerinin sütun grafiğine uygun problem kurma becerilerinin incelenmesi. Mehmet Akif Ersoy Üniversitesi Ĕ̆itim Fakültesi Dergisi, 48, 325-354. doi: 10.21764/maeuefd.390346

Franklin, C., Kader, G., Mewborn, D., Moreno, J., Peck, R., Perry, M., and Scheaffer, R. (2007). Guidelines for assessment and instruction in statistics education (GAISE) report: A preK-12 curriculum framework. Alexandria. VA: American Statistical Association. Erişim adresi:

https:/ / www.amstat.org/asa/education/Guidelines-for-Assessment-andInstruction-in-Statistics-Education-Reports.aspx

Gal, I. (2002). Adults' statistical literacy: Meanings, components, responsibilities. International Statistical Review, 70(1), 1-51. https:// doi.org/10.1111/j.175158232002tb00336.x

González, M. T., Espinel, M. C., and Ainley, J. (2011). Teachers' graphical competence. In C. Batanero, G. Burrill, and C. Reading (Eds.), Teaching statistics in school mathematics-Challenges for teaching and teacher education. A Joint ICMI/IASE Study. New York: Springer.

Güven, B., Öztürk, T. ve Özmen, Z. M. (2015). Ortaokul sekizinci sınıf öğrencilerinin istatistiksel süreçteki becerilerinin incelenmesi. Eğitim ve Bilim Dergisi, 40(177), 343-363. doi: 10.15390/EB.2015.3313

Hafiyusholeh, M., Budayasa, K., and Siswono, T, Y, E. (2018). Statistical literacy: High school students in reading, interpreting and presenting data. Journal of Physics: 
Conf. Series. Erişim adresi: https://iopscience.iop.org/article/10.1088/17426596/947/1/012036/meta

Karatoprak, R., Karagöz-Akar, G., and Börkan, B. (2017). Prospective elementary and secondary school mathematics teachers' statistical reasoning. International Electronic Journal of Elementary Education, 7(2), 107-124.

Koparan, T. ve Güven, B. (2013). İlköğretim ikinci kademe öğrencilerinin istatistiksel düşünme seviyelerindeki farklılaşma üzerine bir araştırma. İlköğretim Online, 12(1), 158-178.

Koparan, T. ve Güven, B. (2014). Ortaokul öğrencilerinin istatistiksel düşünme seviyelerinin M3ST modeline göre incelenmesi. Eğitim ve Bilim, 39(171), 37-51.

Kuş, M., and Çakıroğlu, E. (2020). Prospective mathematics teachers' critical thinking processes about scientific research: Newspaper article example. Turkish Journal of Education, 9(1), 22-45. https:/ / doi.org/10.19128/turje.605456

Lacefield, W. O. (2009). The power of representation: Graphs and glyphs in data analysis lessons for young learners. Teaching Children Mathematics, 15(6), 324326. https:/ / doi.org/10.5951/TCM.15.6.0324

Miles, M. B., and Huberman, A. M. (1994). Qualitative data analysis (second edition). London: SAGE.

Millî Eğitim Bakanlığı [MEB] (2009). İlköğretim matematik dersi 6-8. sınıflar öğretim programı ve kılavuzu. Ankara: Milli Eğitim Bakanlığı Yayınları.

Milli Eğitim Bakanlığı [MEB] (2013). Ortaokul matematik mersi (5, 6, 7 ve 8. sinıflar) öğretim programı. Ankara: Milli Eğitim Bakanlığı.

Milli Eğitim Bakanlığ1 [MEB] (2018). Illkokul ve ortaokul matematik (1, 2, 3, 4, 5, 6, 7 ve 8. Sınıflar) dersi öğretim programı. Ankara: Milli Ĕ̆itim Bakanlığı.

Monteiro, C., and Ainley, J. (2007). Investigating the interpretation of media graphs among student teachers. International Electronic Journal of Mathematics Education, 2(3), 187-207.

National Council of Teachers of Mathematics [NCTM] (2000). Principles and Standards for School Mathematics. Reston, VA: Author.

Özmen, Z. M. ve Baki, A. (2019). 5-8. sınıf matematik öğretim programının istatistik okuryazarlığı bağlamında incelenmesi. Necatibey Eğitim Fakültesi Elektronik Fen ve Matematik Eğitimi Dergisi, 13(2), 1063-1082.

https:// doi.org/10.17522/balikesirnef.603569

Sezgin-Memnun, D. (2013). Ortaokul yedinci sınıf öğrencilerinin çizgi grafik okuma ve yorumlama becerilerinin inclenmesi. Turkish Studies - International Periodical for the Languages, Literature and History of Turkish or Turkic, 8(12), 1153-1167. https:// doi.org/10.7827/TurkishStudies.6026

Shah, P., and Hoeffner, J. (2002). Review of graph comprehension research: Implications for instruction. Educational Psychology Review, 14(1), 47-69. https:// doi.org/10.1023/A:1013180410169

Sharma, S. V. (2005). High school students interpreting tables and graphs: Implications for research. International Journal of Science and Mathematics Education, 4(2), 241-268. https:/ / doi.org/10.1007/s10763-005-9005-8

Sharma, S. V. (2013). Assessing students' understanding of tables and graphs: Implications for teaching and research. International Journal of Educational Research and Technology, 4(4), 51-70. 
Swatton, P., and Taylor, R. M. (1994). Pupil performance in graphical tasks and its relationship to the ability to handle variables. British Educational Research Journal, 20(2), 227-243.

Türkiye İstatistik Kurumu [TÜİK] (2016a). Sektörel enerji tüketim istatistikleri, 2014. Erişim adresi: http://www.tuik.gov.tr/HbPrint.do?id=21587.

Türkiye İstatistik Kurumu [TÜİK] (2016b). Kütüphane istatistikleri, 2015. Erişim adresi: http:/ / www.tuik.gov.tr/PreHaberBultenleri.do;jsessionid=Jh11YpyGp2pTNjr L1JQ21syty6SsXMhSqLnGNcN4DTM0Rw5ZjgLW!644368050?id=21545

Türkiye İstatistik Kurumu [TÜİK] (2017a). Hayvansal üretim istatistikleri, Haziran, 2017.

Erişim adresi:

http:/ / www.tuik.gov.tr/PreHaberBultenleri.do;jsessionid=fZcxhRZQ5Rb19y KJzHQDzRgHlhPjtsTJYdFT11v19G0QnWgn1r5c!557753276?id=24656.

Türkiye İstatistik Kurumu [TÜIK] (2017b). Yazılı medya istatistikleri, 2016. Erişim adresi: http:/ / tuik.gov.tr/PreHaberBultenleri.do?id=24673

Watson, J. M. (2006). Statistical literacy at school: Growth and goals. Mahwah, NJ: Lawrence Erlbaum Associates.

Watson, J., and Callingham, R. (2003). Statistical literacy: A complex hierarchical construct. Statistics Education Research Journal, 2(2), 3-46.

Yanık, H. B., Özdemir, G., and Eryılmaz-Çevirgen, A. (2017). Investigating data processing related tasks in middle school mathematics textbooks. İn̈nü Üniversitesi Ĕ̆itim Fakültesi Dergisi, 18(2), 45-61. doi: 10.17679/inuefd.323407

Yayla, G. ve Özsevgeç, T. (2015). Ortaokul öğrencilerinin grafik becerilerinin incelenmesi: Çizgi grafikleri oluşturma ve yorumlama. Kastamonu Eğitim Dergisi, 23(3), 1381-1400.

Yıldırım, A. ve Şimşek, H. (2006). Sosyal bilimlerde nitel araştırma yöntemleri (6. Baskı). Ankara: Seçkin Yayıncılık.

Yılmaz, N. ve Ay, Z. S. (2016). Sekizinci sınıf öğrencilerinin histograma dair bilgi ve becerilerinin incelenmesi. İlköğretim Online, 15(4), 1280-1298.

https:// doi.org/10.17051/io.2016.66174

\section{Summary}

\section{Introduction}

Every day, people encounter statistical information through newspapers or other media in many places in their daily life. Such information enables people to fulfill their responsibilities as citizens while guiding their decisions in their personal lives (Franklin et al., 2007). For more than a quarter-century, with the increasing importance of statistical thinking and statistical literacy in people's daily lives, statistical teaching and learning has become a key component of the curriculum of mathematics teaching from the pre-school to high school throughout the world. Accordingly, data analysis learning area has gained the same importance in the Turkish mathematics curriculum (Ministry of National Education [MoNE], 2009; 2013 and 2018).

Graphs are an important part of the objectives of the statistics education in the school mathematics curriculum. Graphs are one of the representations that 
summarize the data briefly and visually (Lacefield, 2009). Graphs usually appear in books and educational software and they help students understand both science and social science data (Shah and Hoeffner, 2002). Furthermore, graphs are a tool for explaining, organizing and summarizing text materials found in newspapers, magazines and advertisements (Curcio, 1981). Reading and interpreting statistical graphs is an important part of statistical literacy (Watson, 2006).

As part of a comprehensive study, the aim of this study is to examine the reading and interpreting levels of the graphs of five middle school students studying in a rural area. The following research question guided this study: What are the levels of middle school 7th-grade students' reading and interpreting data presented in graphs?

\section{Method}

This study was conducted during the spring semester of the 2017-2018 academic year at a public middle school located in a rural district of Sivas province. The participants of the study consisted of five (4 girls, 1 boy), 7th-grade students. The convenient sampling method was used in the selection of the school and the classroom, where this study was conducted. Also, the purposive sampling method was used in the selection of five students (Yıldırım and Şimşek, 2006).

The qualitative case study was utilized in this study. For this study, five activities were used to be used to examine the processes and levels of students' graph reading and interpretation. Four of these activities were developed by the researchers of this study. They were implemented in two steps and students worked individually on each activity. After the activities were implemented, the individual interviews were conducted with five participating students to examine students' graph reading and interpretation in more detail. The data sources for this study were students' written activity sheets of including reading and interpreting graphs and activitybased individual interviews. During the interviews, the students were asked the following questions based on their written explanations in their activity sheets. How did you interpret the given graph? What does the graph tell /explain? Why?, How did you determine that the number of library users increased/decreased between the years 2015 and 2016? Can you explain it?

The content analysis was conducted in the analysis of data. In the analysis of the data, the categories presented in related studies in the literature (Aoyama, 2007; Curcio, 1987) were utilized.

\section{Results}

The findings of the study revealed that the students interpreted the graphs, where they were asked to interpret the graphs through an open-ended question for each graph, by reading between data at a very low level, low level and medium level. On the other hand, one of the students interpreted the graphs presented in two activities without reading between data. Moreover, the findings showed that graph interpretation levels of students varied according to activities. In other words, while one student interpreted the graph presented in one activity by reading data at a very low level, the other student interpreted the graph by reading between data at an intermediate level. At the same time, while interpreting the graphs, some students used expressions such as "at least", "at most" based on the visual of the graph without using numerical values. The data displayed that five students interpreted the 
graphs without examining all the data presented in the graphs and evaluating them. They focused only on some data, and they did not tend to interpret the general trend of the graph. However, the findings indicated that the students mostly answered the structured questions that they would answer by reading and comparing the data directly from the graph correctly.

\section{Discussion}

The findings regarding the students' success in reading the data were in line with the findings in previous research. Some studies in the literature (Aoyama, 2007; Hafiyusholeh et al., 2018; Sharma, 2005) commonly revealed that students could read the data presented in the graphs; however, they were generally not able to read the relationships between the data in the graph and they had difficulty in predicting and making inferences based on data. One of the reasons why the participating students were more successful in reading the data than reading between the data can be explained by that students had experience in working on questions regarding the reading the data. The students who participated in this study were more successful in the questions similar to the examples presented in the textbooks. That is, students were more successful in the questions that required to be determined by reading the numerical values of the (qualitative) data. On the other hand, students were less successful than the open-ended question which requires students' interpretation.

\section{Pedagogical Implications}

Students' reading and interpreting levels of graphical data is an important part of statistical literacy (Watson, 2006). Students' reading and interpreting the information presented graphically are important skills not only in school mathematics classes but also in their daily lives. Therefore, this study suggested that mathematics teachers should include activities to improve students' statistical literacy and interpreting and evaluating statistical information critically.

\section{Araştırmanın Etik Taahhüt Metni}

Yapılan bu çalışmada bilimsel, etik ve alıntı kurallarına uyulduğu; toplanan veriler üzerinde herhangi bir tahrifatın yapılmadığı, karşılaşılacak tüm etik ihlallerde "Cumhuriyet Uluslararası Eğitim Dergisi ve Editörünün" hiçbir sorumluluğunun olmadığı, tüm sorumluluğun Sorumlu Yazara ait olduğu ve bu çalışmanın herhangi başka bir akademik yayın ortamına değerlendirme için gönderilmemiş olduğu sorumlu yazar tarafından taahhüt edilmiştir.

\section{Authors' Biodata/ Yazar Bilgileri}

Hatice Kübra GÜLER Milli Eğitim Bakanlığı'nda matematik öğretmeni olarak çalışmaktadır. Tokat Gaziosmanpaşa Üniversitesi Eğitim Bilimleri Enstitüsü'nde Yüksek Lisans Tez çalışmasını tamamlamıştır.

Hatice Kübra Güler is a mathematics teacher at Ministry of National Education of Turkey. She completed her Master's thesis in the Institute of Educational Sciences of Tokat Gaziosmanpasa University. 
Makbule Gözde DİDIŞ KABAR Tokat Gaziosmanpaşa Üniversitesi, Eğitim Fakültesi, Matematik ve Fen Bilimleri Eğitimi Bölümünde öğretim üyesi olarak görev yapmaktadır. Başlıca çalışma alanları arasında matematik öğretmen eğitimi ve matematiksel modelleme yer almaktadir.

Makbule Gözde Didiş Kabar works an instructor at Tokat Gaziosmanpasa University, Faculty of Education, Mathematics and Science Education Department. Her main research areas include mathematics teacher education and mathematical modeling. 